\title{
Diagnosis and Management of Lung Infections
}

Dawn E. Jaroszewski, MD, MBA ${ }^{a, *}$, Brandon J. Webb, MD ${ }^{b}$, Kevin O. Leslie, $M^{c}$

\section{KEYWORDS}

- Pulmonary infection $\bullet$ Hemoptysis $\bullet$ Antibiotic therapy for pneumonia $\bullet$ Fungal pneumonia

- Community-acquired pneumonia $\bullet$ Hospital acquired pneumonia $\bullet$ Ventilator associated pneumonia

\section{KEY POINTS}

- Thoracic surgeons are often called on to assist in the diagnosis and sometimes treatment of complicated pulmonary and thoracic infections.

- Modern diagnostic techniques used to obtain microbiological and pathologic specimens include bronchoscopy, ultrasound- and electromagnetic-guided endoscopy, transthoracic biopsy, and thoracoscopy.

- Appropriate empiric treatment of bacterial pulmonary infection requires categorization according to risk factors for drug-resistant pathogens; categories include community-acquired, health careassociated, hospital-acquired, and ventilator-associated pneumonia.

- Treatment of fungal and mycobacterial disease is heavily dependent on correct diagnosis; fungal pathogens include endemic fungi, yeast, and invasive molds, whereas mycobacterial infection may be caused Mycobacterium tuberculosis complex or nontuberculous mycobacterium.

- Recent advances in treatment, including topical antimicrobial therapy and direct endoscopic intervention, are promising in the treatment of multidrug-resistant infection and hemoptysis.

\section{INTRODUCTION}

Thoracic surgeons occasionally must be involved in the diagnosis and treatment of respiratory tract infections. In addition to the complication of postoperative pneumonia in surgical patients, assistance may be needed for diagnosing radiographic abnormalities, community-acquired pneumonia (CAP), nosocomial pneumonia, ventilator-associated pneumonia (VAP), and pneumonia in the immunocompromised host. Although most clinically significant infections can be identified with respiratory cultures and microbiologic analysis, a small percentage of infections require a surgical pathologist for definitive diagnosis. ${ }^{1}$

The spectrum and burden of etiologic organisms are affected by host risk factors and immune status. ${ }^{2-7}$ Because organisms are found less often in the lung tissue of patients with normal immunity, diagnosis can be facilitated by cultures, serologic studies, and epidemiologic data. ${ }^{8}$ In the immunocompromised host, a broader differential must be considered, including the possibility of multiple simultaneous infections.

In addition to infection, other disorders should be considered, such as pulmonary involvement by

The authors have no disclosures or funding sources.

a Division of Cardiothoracic Surgery, Department of Surgery, Mayo Clinic, Arizona, 5777 East Mayo Boulevard, Phoenix, AZ 85054, USA; ' Department of Internal Medicine, Mayo Clinic Arizona, 5777 East Mayo Boulevard, Phoenix, AZ 85054, USA; ' Department of Laboratory Medicine and Pathology, Mayo Clinic Arizona, 5777 East Mayo Boulevard, Phoenix, AZ 85054, USA

* Corresponding author.

E-mail address: jaroszewski.dawn@mayo.edu 
preexisting disease, drug-induced or treatmentrelated injury, noninfectious interstitial pneumonias, and malignancy. Appropriate chest imaging may help narrow the differential. This information, when combined with clinical history and the timing of the disease (acute, subacute, or chronic), is critical to a successful treatment strategy. This article reviews the current diagnostic modalities and medical treatment recommendations for pulmonary infections.

\section{DIAGNOSIS}

The successful treatment of pulmonary infections depends on accurate identification of the precipitating pathogen. In contemporary medical practice, distinction of the genus or species of an infectious organism can have important prognostic and therapeutic implications. Suspected pulmonary infections should be defined by (1) signs and symptoms consistent for diagnosing a pneumonia, (2) clinical setting consistent with acquisition of pneumonia, (3) host susceptibility predisposing to pneumonia, and (4) exposure and risk factors of specific pathogens. ${ }^{9}$

For pneumonia, sputum collection with microscopic examination and culture of expectorant is the mainstay of laboratory evaluation. Although simple, quick, and inexpensive, sputum cultures are nonetheless negative for growth $50 \%$ of the time despite proven infections. Contamination with oropharynx secretions is also a frequent issue. If sputum evaluation fails to identify causative factors and definitive identification is required for successful patient treatment, more invasive sampling techniques are available, including bronchoscopy, transthoracic needle aspiration or core

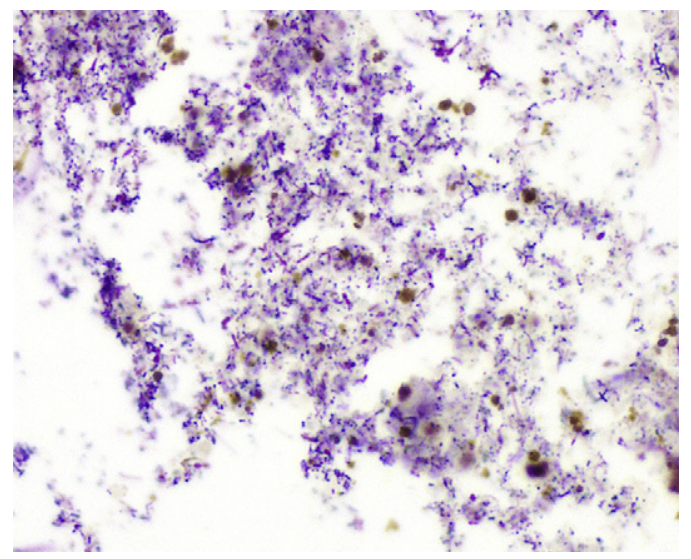

Fig. 1. Microscopy showing acute exudate with mixed gram-positive (b/ue) and gram-negative (red) bacterial organisms. Gram stain, original magnification, $\times 400$.

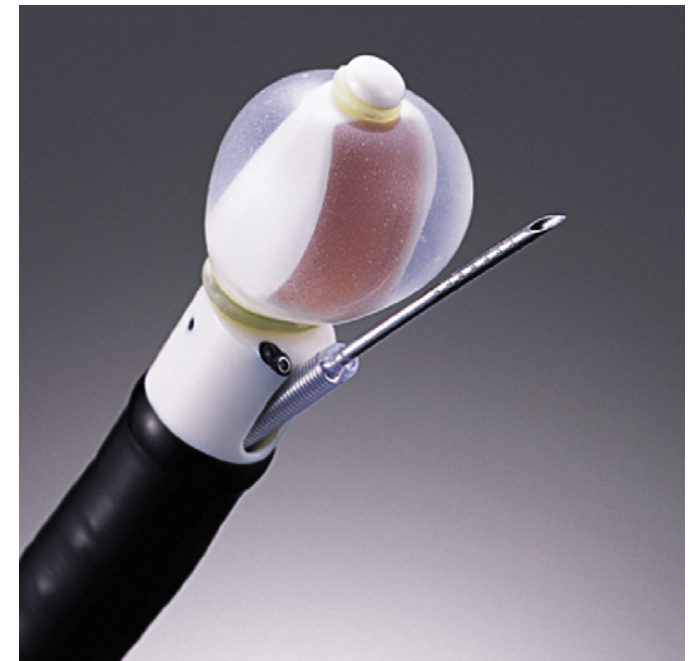

Fig. 2. An Olympus Endoscopic Ultrasound. (Courtesy of Olympus America, Inc, Center Valley, PA; with permission.)

biopsy, and surgical wedge biopsy of peripheral lung using a transthoracic approach. ${ }^{10-17}$

\section{Specimens Obtained Through the Flexible Bronchoscope}

Current pulmonary endoscopy is dominated by the flexible bronchoscope. Its flexibility provides the advantage of better access to more distal airways. ${ }^{18,19}$ Lavage and washings can be

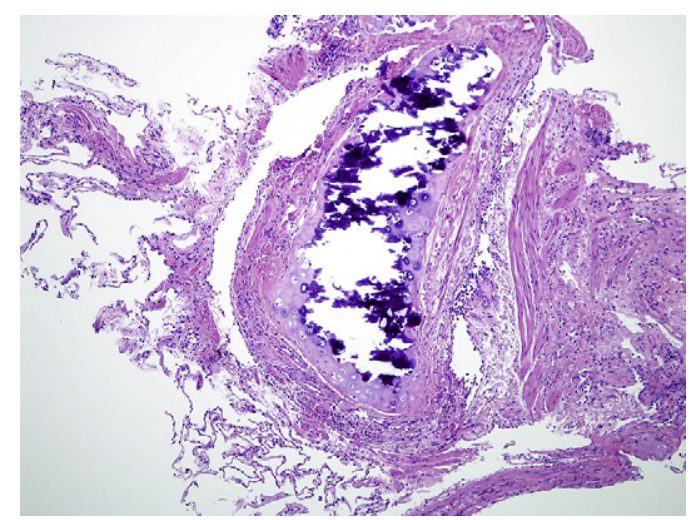

Fig. 3. Microscopy of transbronchial biopsies taken blindly are intended to represent alveolar lung parenchyma. Sometimes these samples are dominated by bronchial mucosa and cartilage if a branch point is directly sampled (a minor carina). This sample shows airway mucosa, lamina propria, and musculature samples with fragments of partially ossified (dark blue) cartilage. Scant alveolar parenchyma is present in the lower left of this image. Hematoxylin and eosin stain, original magnification, $\times 100$. 
aspirated and the fluid sample of suspended cells can be sent to the laboratory for millipore filtration or cytocentrifuge-type application onto slides (Fig. 1). ${ }^{14,17,20-22}$ Clinical guidelines confirm the value of a bronchoscopic approach to diagnosis, particularly in patients with VAP, in whom it has been shown to reduce 14-day mortality. ${ }^{23,24}$

Endobronchial ultrasound has also added to the available diagnostic options (Fig. 2). Both transbronchial lung biopsy of peripheral pulmonary lesions and sampling of mediastinal and hilar lymph nodes may provide access to infectious pathogens that cannot be identified otherwise. ${ }^{25,26}$

The transbronchial biopsy technique allows obtainment of samples of alveolar lung parenchyma beyond the cartilaginous bronchi. ${ }^{17,19,20,27}$ Endoscopic transbronchial biopsies taken blindly are intended to represent alveolar lung parenchyma. Sometimes these samples have bronchial mucosa and cartilage if a branch point, such as a minor carina, is sampled directly (Fig. 3). Many types of pulmonary infections can be diagnosed using fine needle aspiration and cytologic evaluation. ${ }^{28-31}$ Fine needle aspiration is an especially useful technique, because respiratory secretions (eg, sputum, bronchial washings, brushings, bronchoalveolar lavage) are often limited by the need to differentiate true pathogens from contaminant organisms. Nevertheless, these diagnostic tools are complementary and both remain excellent options in the diagnosis of localized or diffuse pulmonary infection. Electromagnetic navigation bronchoscopy has proven effective in assessing pulmonary nodules accurately with low complication rates. Electromagnetic navigation bronchoscopy uses computer guidance to enable bronchoscopic access to pulmonary lesions (Fig. 4). ${ }^{32,33}$

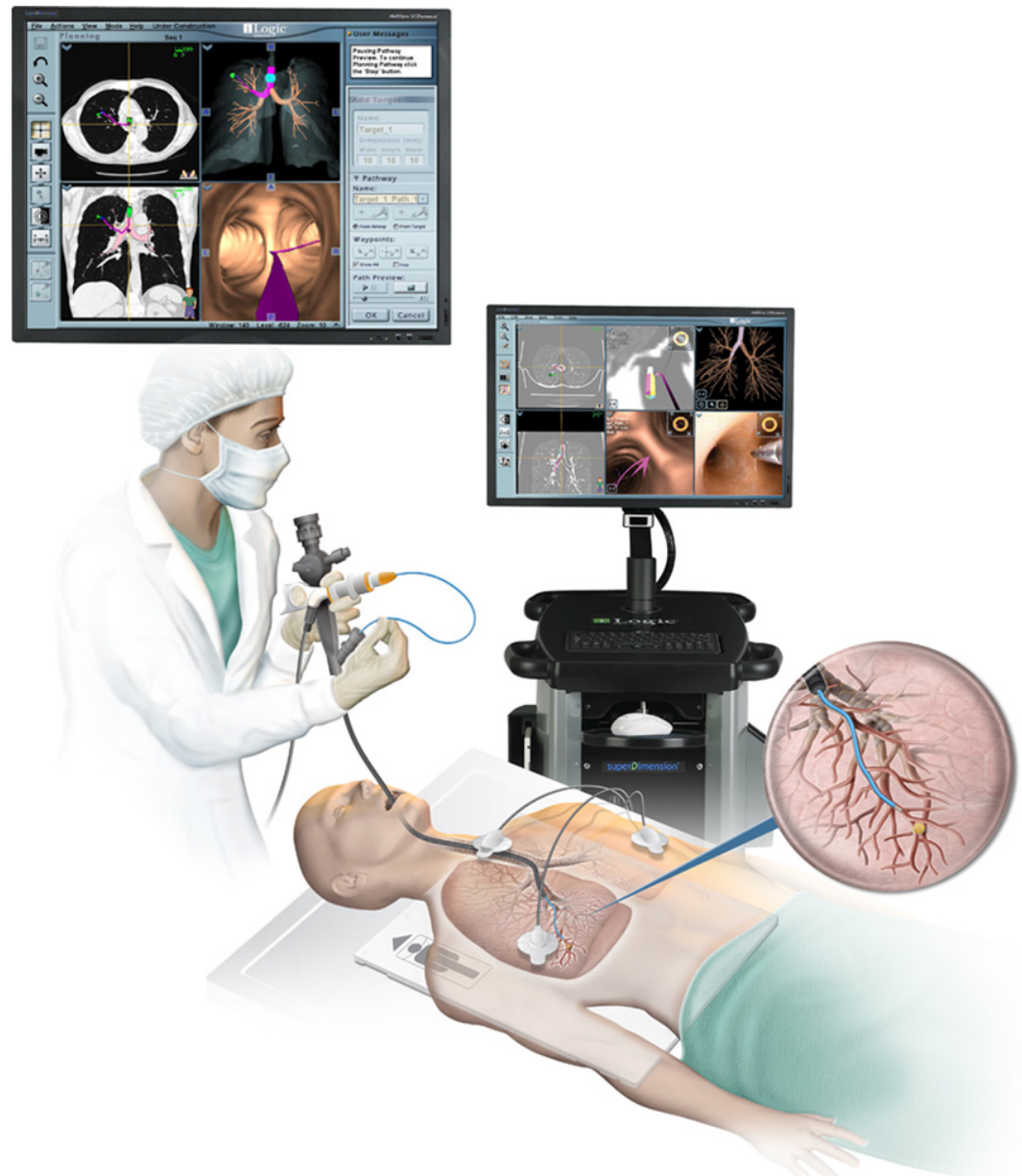

Fig. 4. The iLogic Electromagnetic Navigation Bronchoscopy allows virtual planning and biopsy of pulmonary lesions. (Courtesy of SuperDimension, Inc, Minneapolis, MN; with permission.) 


\section{Specimens Obtained With Transthoracic Needle Biopsy, Aspiration, and Cores}

Contamination can be minimized when the upper respiratory tract can be bypassed. With either transtracheal or transthoracic needle aspiration, the presence of bacteria becomes much more significant, especially when sheets of neutrophils and/or necroinflammatory debris are present (Fig. 5), as would be the case with a typical lobar or lobular consolidation, lung abscess, or other complex pneumonia (Fig. 6). ${ }^{34-37}$ In this context, transthoracic needle aspiration can establish the etiologic diagnosis of CAP and nosocomial pneumonia when coupled with contemporary microbiologic methods. ${ }^{38-41}$ In current practice, the use of transthoracic needle aspiration biopsy has become commonplace, ${ }^{16,42-47}$ and it is often used to target well-circumscribed nodules when an infectious process must be ruled out (Fig. 7). Besides the morphologic features of the microorganism, important cytologic clues to the diagnosis include the accompanying cellular response and the presence and character of any necrotic debris. Anaerobic pulmonary infections, typically in the form of a lung abscess, can also be approached in this way or with transthoracic needle aspiration (Fig. 8). ${ }^{48}$

In some cases, core biopsy is preferable to an aspirate. Needle core biopsies may provide better and more abundant diagnostic tissue, whereas aspirate is preferred when evaluating suspected bacterial abscess. Based on the microscopic features of the organism obtained, this technique may yield rapid diagnostic results. ${ }^{39}$

In addition to respiratory samples, pleural fluid can be tapped when effusions are present. Positive cultures of these normally sterile fluids circumvent the interpretive problems associated with bacterial growth in sputum samples. Persistent

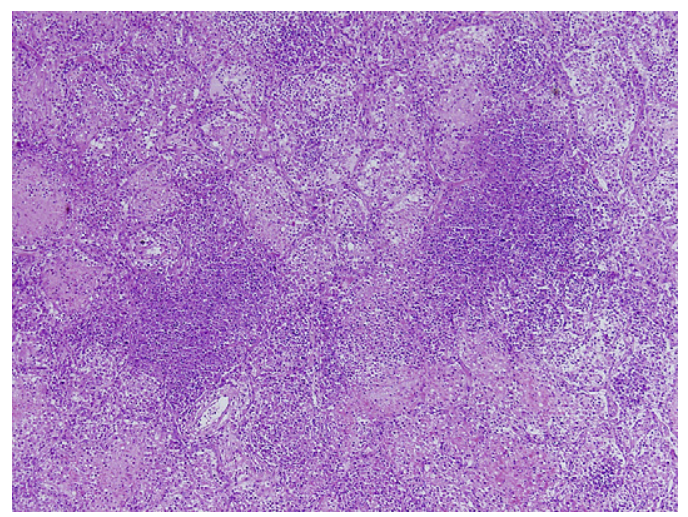

Fig. 5. Microscopy showing sheets of neutrophils and necrotic inflammation.

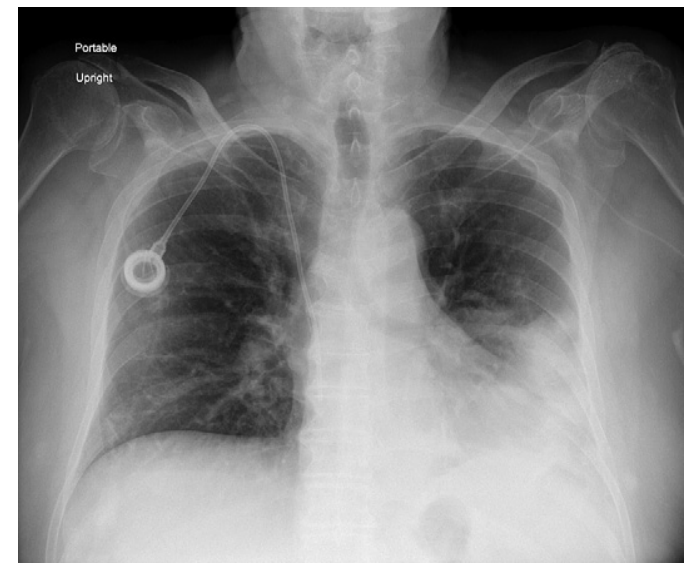

Fig. 6. Chest radiograph showing a lobar pneumonia with consolidation pneumonia in the left lower lobe.

effusions and suspected empyema can be easily analyzed with thoracentesis (Fig. 9). ${ }^{49-51}$

\section{Specimens Obtained Through Thoracoscopy}

Surgical biopsy of lung parenchyma is indicated to distinguish infection from interstitial and inflammatory lung disease. The introduction of high-resolution video equipment has changed elective thoracic surgery. With small incisions and a thoracoscopic video camera (Fig. 10), surgeons can directly biopsy affected lung tissue, with large quantities of parenchyma available for both microbiologic and pathologic evaluation (Fig. 11). Video-assisted thoracic surgery has become the standard approach for most surgical biopsies. Mortality is low and length of hospital stay and recovery are improved over those with the standard thoracotomy. ${ }^{52}$ When the same thoracic access ports are used,

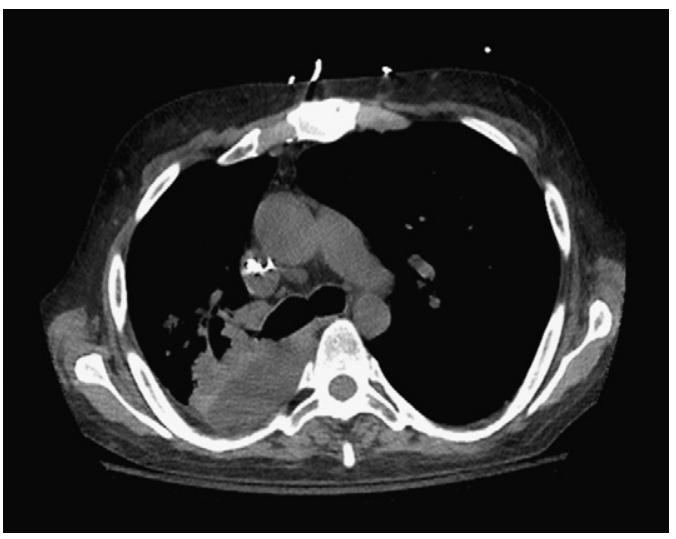

Fig. 7. CT scan showing consolidation secondary to severe lobar pneumonia and consolidation in the right lower lobe. 


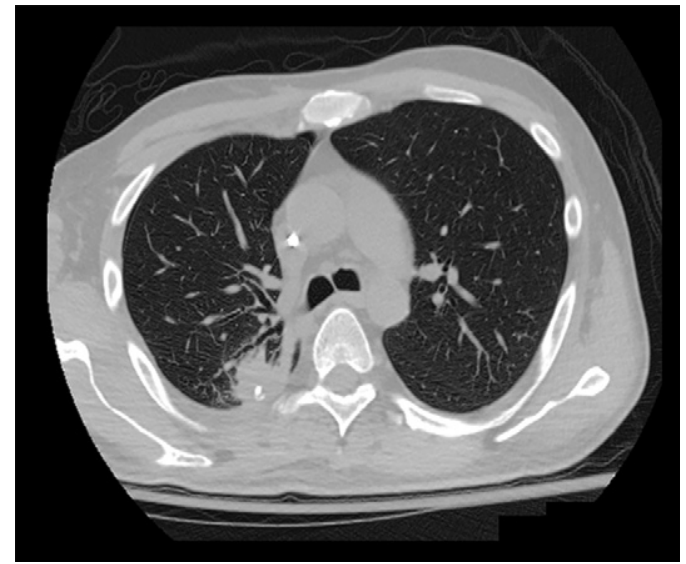

Fig. 8. CT scan showing a nodular abscess in the right lower lobe.

ipsilateral lymph nodes that may contain disease or abnormalities can be biopsied simultaneously. Before a wedge lung biopsy is performed, consultation among the radiologist, chest physician, and thoracic surgeon is essential to identify ideal locations for biopsy.

\section{CAUSES AND TREATMENT OF PULMONARY INFECTION}

Pneumonia may be classified according to several parameters, including pathogenesis, epidemiology, anatomic pattern (see Fig. 4), clinical course, and organism. ${ }^{53}$ In this article, pulmonary bacterial infection is divided into CAP, health care-associated pneumonia (HCAP), hospital-acquired pneumonia (HAP), and VAP. Mycobacterial, fungal, and viral infections are also addressed because these entities require special diagnostic and treatment considerations. The pathologic patterns and

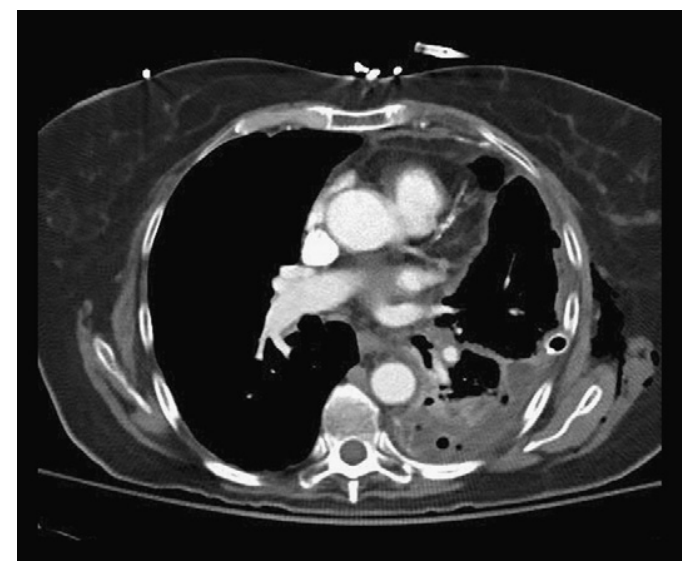

Fig. 9. CT scan showing a large pleural empyema on the left.

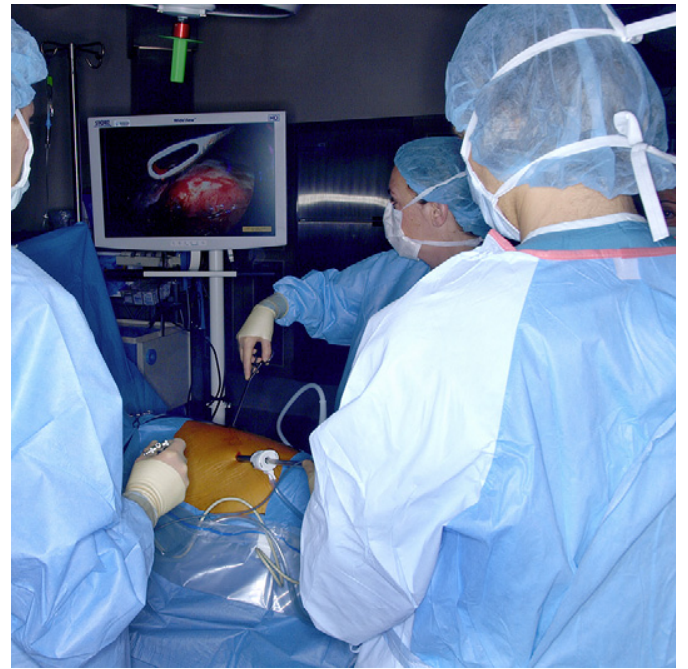

Fig. 10. Minimally invasive surgery with video images allows biopsy of parenchyma and lymph nodes for evaluation.

agents of the most common pulmonary infections are listed in Table 1.

\section{CAP}

CAP is defined as pneumonia acquired in an outpatient setting by patients in whom common lower respiratory pathogens are suspected. Although viruses (Fig. 12) and endemic fungi may cause CAP, the definition and treatment regimens presuppose a bacterial origin. The most common origins are listed in Table 2 (Figs. 13 and 14A, B). Coverage of these agents forms the basis for initial empiric treatment of CAP. However, clinicians must be aware of factors that predispose patients to pneumonia caused by drug-resistant bacteria, such as methicillin-resistant Staphylococcus

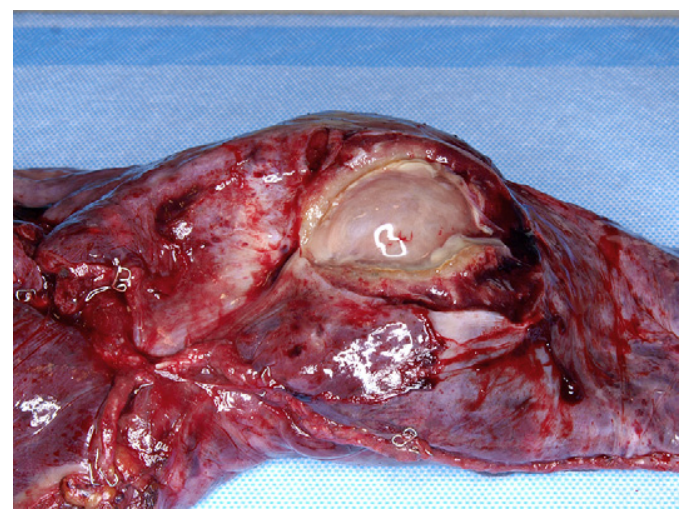

Fig. 11. A wedge biopsy from minimally invasive thoracic surgery shows a large cavitary fungal infection. 


\section{Table 1}

Pathologic patterns and agents of pulmonary infection

\section{Pattern}

Most Common Agents

Airway disease

Bronchitis/bronchiolitis

Bronchiectasis

Virus; bacteria; mycoplasma

Acute exudative pneumonia

Purulent (neutrophilic)

Lobular (bronchopneumonia)

Bacteria; mycobacteria

Confluent (lobar pneumonia)

With granules

Eosinophilic

Foamy alveolar cast

Acute diffuse/localized alveolar damage

Bacteria

Bacteria

Chronic pneumonia

Fibroinflammatory

Bacteria

Organizing diffuse/Localized alveolar damage

Botryomycosis; actinomycosis

Eosinophilic

Histiocytic

Parasites

Pneumocystis

Virus; polymicrobial

Interstitial pneumonia

\begin{tabular}{ll}
\hline Perivascular lymphoid & Virus; atypical agents \\
\hline Eosinophilic & Parasite \\
\hline Granulomatous & Mycobacteria \\
\hline Nodules & \\
\hline Large & Fungi; mycobacteria \\
\hline Necrotizing & Fungi; mycobacteria \\
\hline Granulomatous & Fungi; mycobacteria \\
\hline Fibrocaseous & Fungi; mycobacteria \\
\hline Calcified & \\
\hline Miliary & Viral; mycobacteria; fungi \\
\hline Necrotizing & Fungi \\
\hline Granulomatous & Fungi; mycobacteria \\
\hline Cavities and cysts & Fungi \\
\hline Intravascular/Infarct & Mycobacteria \\
\hline Spindle cell pseudotumor & Polymicrobial \\
\hline Minimal “Id"type reaction
\end{tabular}

From Jaroszewski DE, Viggiano RW, Leslie KO. Optimal processing of diagnostic lung specimens. In: Leslie KO, Wick MR, editors. Practical pulmonary pathology: a diagnostic approach, 2nd edition. Philadelphia: Elsevier/Saunders; 2011. (Pattern Recognition Series). p. 15-25; with permission.

aureus (MRSA) or Pseudomonas aeruginosa; antibiotic selection for these patients should take into consideration additional breadth of spectrum (Box 1). ${ }^{23}$

\section{Treatment of CAP}

The American Thoracic Society and the Infectious Disease Society of America have published joint guidelines on the diagnosis and management of
CAP. Box $2^{55}$ summarizes the recommended empiric antibiotics for CAP. Recommended treatment regimens vary based on severity of illness and setting (eg, outpatient, inpatient, intensive care). For empiric inpatient therapy, strong evidence supports use of either a respiratory fluoroquinolone or a combination of a $\beta$-lactam plus a macrolide. ${ }^{56} \mathrm{In}$ patients requiring intensive care, guidelines recommend a $\beta$-lactam plus a fluoroquinolone. ${ }^{55}$ However, in this critically ill population, in whom 


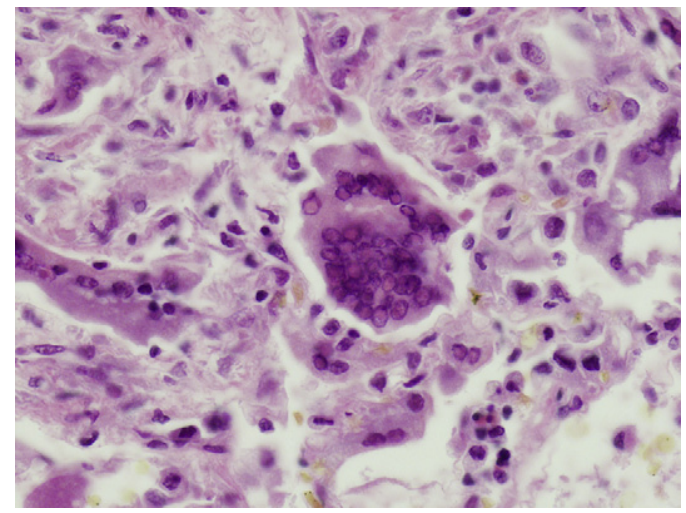

Fig. 12. Multinucleated cell with glassy viral nuclear inclusions consistent with a measles virus are identified in a patient with measles pneumonia. (hematoxylin-eosin, original magnification, $\times 400$ ).

the margin for error is low, many clinicians favor an initial broad-spectrum regimen that includes antiMRSA and antipseudomonal coverage.

If an etiologic agent is identified, antimicrobial therapy should be narrowed to target that pathogen (Table 3). Guidelines recommend that before

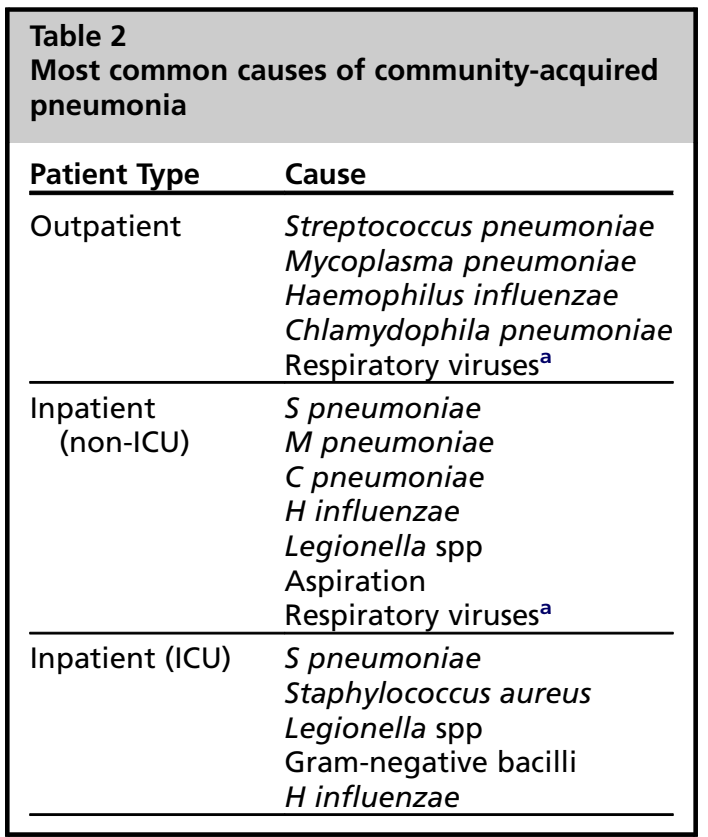

Based on collective data from recent studies. ${ }^{54}$

Abbreviation: ICU, intensive care unit.

a Influenza A and B, adenovirus, respiratory syncytial virus, and parainfluenza.

From Mandell LA, Wunderink RG, Anzueto A, et al. Infectious Diseases Society of America/American Thoracic Society consensus guidelines on the management of community-acquired pneumonia in adults. Clin Infect Dis 2007;44:S27-72; with permission.

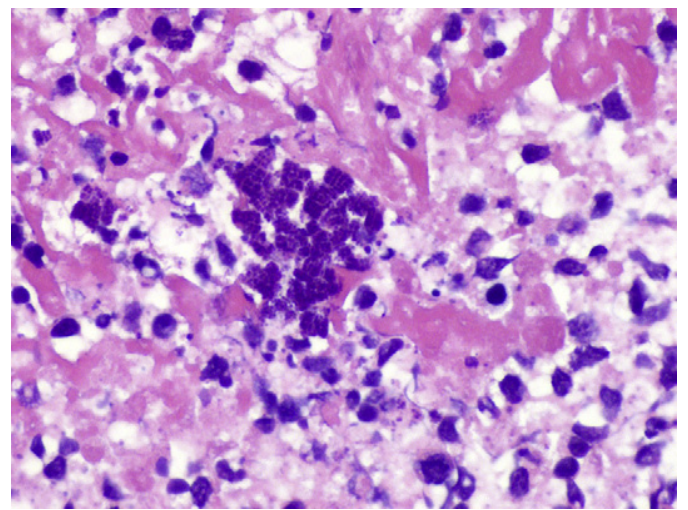

Fig. 13. Staphyloccocal organisms (center) in a necrotizing pneumonia. Aggregated bacteria tend to be dark blue in routine stains. Hematoxylin and eosin stain, original magnification, $\times 400$.

discontinuation of therapy, a minimum of 5 days of treatment should occur, and patients should have achieved clinical stability as evidenced by the absence of fever for greater than 48 hours, hypoxia, tachypnea, tachycardia, and hypotension. Patients can be safely switched from intravenous to oral therapy when they are hemodynamically stable and able to absorb oral medication. ${ }^{58,59} \mathrm{~A}$ longer duration of therapy may be necessary if the patient does not experience improvement, the identified pathogen was not sensitive to initial empiric therapy, or an extrapulmonary infection is present.

\section{HCAP}

A subset of patients presenting with pneumonia acquired in the community will have risk factors for disease caused by drug-resistant pathogens (DRP). In the 2005 guidelines from the American Thoracic Society and the Infectious Diseases Society of America (ATS/IDSA) for HAP and VAP, an additional category, HCAP, was proposed to the existing paradigm. ${ }^{23}$ These patients share risk factors for DRP with those susceptible to HAP and VAP, including exposure to $P$ aeruginosa, extended spectrum $\beta$-lactamase producing Escherichia coli and Klebsiella, Acinetobacter, Burkholderia, drug-resistant Enterobacteriaceae, and MRSA. Included in the new classification are patients hospitalized within the past 90 days; those receiving chemotherapy, wound care, or intravenous antibiotics; residents of nursing homes or long-term facilities; and patients undergoing hemodialysis. For these patients, the guidelines recommend a more aggressive empiric antibiotic regimen, including an antipseudomonal $\beta$ lactam plus either an aminoglycoside or an 

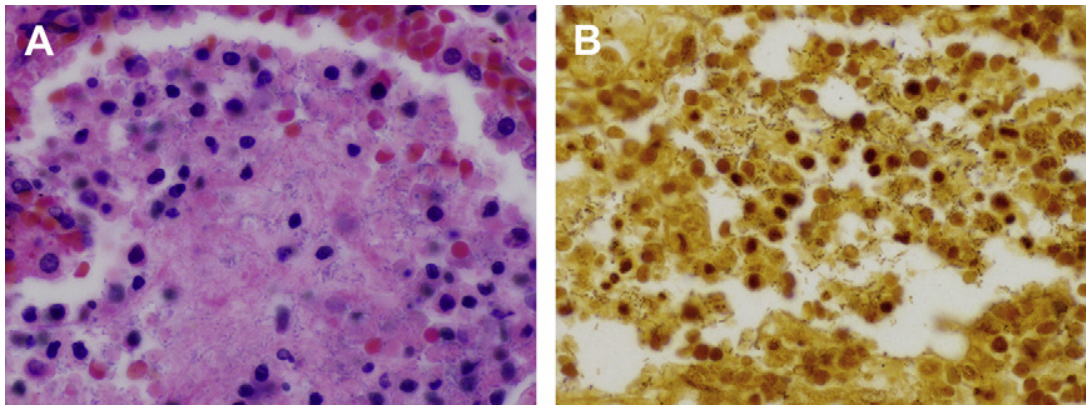

Fig. 14. Streptococcus pneumoniae infection. $(A)$. On routine hematoxylin and eosin staining, the organisms present a fine granular blue appearance in a background of more eosinophilic fibrinous exudate. The round blue structure are the nuclei of degenerated inflammatory cells. (B) Silver impregnation methods highlight many bacterial forms, making their morphology more discernible in black (Dieterle silver stain). Both images original magnification, $\times 400$.

antipseudomonal fluoroquinolone, plus an agent active against MRSA if risk factors for MRSA are present (Table 4).

\section{HAP}

Nosocomial pneumonia is generally subdivided into HAP, including postoperative pneumonia, and VAP. HAP is defined as pneumonia occurring in patients hospitalized for longer than 48 hours

\section{Box 1 \\ Risk factors for multidrug-resistant pathogens causing HAP, HCAP, and VAP}

- Antimicrobial therapy in preceding 90 days

- Current hospitalization of 5 days or more

- High frequency of antibiotic resistance in the community or in the specific hospital unit

- Presence of risk factors for HCAP

- Hospitalization for 2 days or more in the preceding 90 days

- Residence in a nursing home or extended care facility

- Home infusion therapy (including antibiotics)

- Chronic dialysis within 30 days

- Home wound care

- Family member with multidrug-resistant pathogen

- Immunosuppressive disease and/or therapy

Reprinted with permission of the American Thoracic Society. Copyright (c) 2012 American Thoracic Society. Guidelines for the management of adults with hospital-acquired, ventilator-associated, and healthcare-associated pneumonia. Am J Respir Crit Care Med 2005;171:388-416. Official journal of the American Thoracic Society. before onset and is associated with high mortality rates. ${ }^{23}$ The treatment algorithm for HAP is based on individual risk for DRP (see Box 1) and time of onset. Patients with no preexisting risk factors for DRP in whom early HAP develops (within the first four hospital days) may be treated with a $\beta$-lactam such as a third-generation cephalosporin, ampicillin-sulbactam, or ertapenem, or with a respiratory fluoroquinolone such as levofloxacin. Patients with late-onset HAP (five or more inpatient days) or with risk factors for DRP should be treated with a broad-spectrum regimen (see Table 4). ${ }^{23}$

\section{VAP}

VAP is defined as pneumonia occurring more than 48 hours after initiation of endotracheal intubation and mechanical ventilation. ${ }^{60}$ Prior hospitalization within the past 90 days or prior antibiotic therapy predisposes to colonization and infection with antibiotic-resistant pathogens. ${ }^{61}$ Suspected cases of VAP should be reviewed for risk factors and signs of antibiotic multidrug resistance (MDR) (Fig. 15).

VAP is the most frequently acquired infection in intensive care units (ICUs), with an incidence of $6 \%$ to $52 \% .{ }^{60}$ Generally, VAP is more prevalent in surgical ICUs than in medical ICUs. ${ }^{60}$ Risk factors for VAP include both host and intervention factors (Table 5). The microbes commonly associated with VAP are similar to those that cause HAP (Table 6). VAP caused by more than one pathogen was identified in $30 \%$ to $70 \%$ of cases. ${ }^{60,61}$ Treatment with initial empiric therapy should be guided by the risk for MDR pathogens as described earlier for HCAP and HAP (Table 7). A strategy for deescalation from an empiric broad-spectrum, multidrug regimen to a targeted therapy with a narrower 
Box 2

Recommended empiric antibiotics for CAP

Outpatient treatment

1. Previously healthy and no use of antimicrobials within the previous 3 months

A macrolide (strong recommendation; level I evidence)

Doxycycline (weak recommendation; level III evidence)

2. Presence of comorbidities, such as chronic heart, lung, liver, or renal disease; diabetes mellitus; alcoholism; malignancies; asplenia; immunosuppressing conditions; or use of immunosuppressing drugs; or use of antimicrobials within the previous 3 months (in which case an alternative from a different class should be selected)

A respiratory fluoroquinolone: moxifloxacin, gemifloxacin, or levofloxacin (750 mg) (strong recommendation; level I evidence)

A $\beta$-lactam plus a macrolide (strong recommendation; level I evidence)

3. In regions with a high rate $(>25 \%)$ of infection with high-level (minimum inhibitory concentration $\geq 16 \mu \mathrm{g} / \mathrm{mL}$ ) macrolide-resident Streptococcus pneumoniae, consider use of alternative agents listed in \#2 for patients without comorbidities (moderate recommendation; level III evidence)

Inpatients, non-intensive care unit treatment

A respiratory fluoroquinolone (strong recommendation; level I evidence)

A $\beta$-lactam plus a macrolide (strong recommendation; level I evidence)

Inpatients, intensive care unit treatment

A $\beta$-lactam (cefotaxime, ceftriaxone, or ampicillin-sulbactam) plus either azithromycin (moderate recommendation; level II evidence) or a respiratory fluoroquinolone (strong recommendation; level I evidence)

For patients allergic to penicillin, a respiratory fluoroquinolone and aztreonam are recommended

Special concerns

If Pseudomonas is a consideration

An antipneumococcal or antipseudomonal $\beta$-lactam (piperacillin-tazobactam, cefepime, imipenem, or meropenem) plus either ciprofloxacin or levofloxacin (750 mg)

or

The above $\beta$-lactam plus an aminoglycoside and azithromycin

or

The above $\beta$-lactam plus an aminoglycoside and an antipneumococcal fluoroquinolone (for patients allergic to penicillin, substitute aztreonam for above $\beta$-lactam) (moderate recommendation; level III evidence)

If community-acquired MRSA is a consideration, add vancomycin or linezolid (moderate recommendation; level III evidence)

Modified from Mandell LA, Wunderink RG, Anzueto A, et al. Infectious Diseases Society of America/American Thoracic Society consensus guidelines on the management of community-acquired pneumonia in adults. Clin Infect Dis 2007;44:S27-72; with permission.

spectrum is recommended to reduce antibiotic use and the selective pressure for MDR bacteria. ${ }^{62,63}$

\section{Aerosolized Antibiotic Therapy in the ICU}

A growing body of data suggests that aerosolized antibiotics may have a role in the treatment of pulmonary infections in mechanically ventilated patients. ${ }^{64,65}$ Several aerosolized antibiotics have been described in the literature for off-label use (Box 3). Several small randomized controlled trials comparing systemic antibiotics plus aerosolized agents versus systemic treatment alone have recently shown a reduction in clinical pulmonary 
Table 3

Recommended antimicrobial therapy for specific pathogens

\begin{tabular}{|c|c|c|}
\hline Organism & Preferred Antimicrobial(s) & Alternative Antimicrobial(s) \\
\hline \multicolumn{3}{|c|}{ Streptococcus pneumoniae } \\
\hline $\begin{array}{l}\text { Penicillin-nonresistant; } \\
\mathrm{MIC}<2 \mu \mathrm{g} / \mathrm{mL}\end{array}$ & Penicillin G, amoxicillin & $\begin{array}{l}\text { Macrolide, cephalosporins } \\
\text { (oral [cefpodoxime, } \\
\text { cefprozil, cefuroxime, } \\
\text { cefdinir, cefditoren] or } \\
\text { parenteral [cefuroxime, } \\
\text { ceftriaxone, cefotaxime]), } \\
\text { clindamycin, doxycycline, } \\
\text { respiratory } \\
\text { fluoroquinolone } \\
\text { a }\end{array}$ \\
\hline $\begin{array}{l}\text { Penicillin-resistant; } \\
\text { MIC } \geq 2 \mu \mathrm{g} / \mathrm{mL}\end{array}$ & $\begin{array}{l}\text { Agents chosen based on } \\
\text { susceptibility, including } \\
\text { cefotaxime, ceftriaxone, } \\
\text { fluoroquinolone }\end{array}$ & $\begin{array}{l}\text { Vancomycin, linezolid, high- } \\
\text { dose amoxicillin ( } 3 \mathrm{~g} / \mathrm{d} \text { with } \\
\text { penicillin } \mathrm{MIC} \leq 4 \mu \mathrm{g} / \mathrm{mL} \text { ) }\end{array}$ \\
\hline
\end{tabular}

Haemophilus influenzae

\begin{tabular}{|c|c|c|}
\hline Non- $\beta$-lactamase-producing & Amoxicillin & $\begin{array}{l}\text { Fluoroquinolone, doxycycline, } \\
\text { azithromycin, } \\
\text { clarithromycin }^{\text {b }}\end{array}$ \\
\hline$\beta$-Lactamase-producing & $\begin{array}{l}\text { Second- or third-generation } \\
\text { cephalosporin, amoxicillin- } \\
\text { clavulanate }\end{array}$ & $\begin{array}{l}\text { Fluoroquinolone, doxycycline, } \\
\text { azithromycin, } \\
\text { clarithromycin }^{\text {b }}\end{array}$ \\
\hline $\begin{array}{l}\text { Mycoplasma pneumoniae/ } \\
\text { Chlamydophila } \\
\text { pneumoniae }\end{array}$ & Macrolide, a tetracycline & Fluoroquinolone \\
\hline Legionella spp & $\begin{array}{c}\text { Fluoroquinolone, } \\
\text { azithromycin }\end{array}$ & Doxycycline \\
\hline Chlamydophila psittaci & A tetracycline & Macrolide \\
\hline Coxiella burnetii & A tetracycline & Macrolide \\
\hline Francisella tularensis & Doxycycline & Gentamicin, streptomycin \\
\hline Yersinia pestis & Streptomycin, gentamicin & Doxycycline, fluoroquinolone \\
\hline Bacillus anthracis (inhalation) & $\begin{array}{l}\text { Ciprofloxacin, levofloxacin, } \\
\text { doxycycline (usually with } \\
\text { second agent) }\end{array}$ & $\begin{array}{l}\text { Other fluoroquinolones; } \\
\beta \text {-lactam, if susceptible; } \\
\text { rifampin; clindamycin; } \\
\text { chloramphenicol }\end{array}$ \\
\hline Enterobacteriaceae & $\begin{array}{l}\text { Third-generation } \\
\text { cephalosporin, } \\
\text { carbapenem (preferred } \\
\text { drug if extended-spectrum } \\
\beta \text {-lactamase producer) }\end{array}$ & $\begin{array}{l}\beta \text {-lactam } / \beta \text {-lactamase } \\
\quad \text { inhibitor, }{ }^{\mathbf{d}} \text { fluoroquinolone }\end{array}$ \\
\hline Pseudomonas aeruginosa & $\begin{array}{l}\text { Antipseudomonal } \beta \text {-lactam } \\
\text { plus (ciprofloxacin or } \\
\text { levofloxacin }{ }^{\text {f or }} \\
\text { aminoglycoside) }\end{array}$ & $\begin{array}{l}\text { Aminoglycoside plus } \\
\text { (ciprofloxacin or } \\
\text { levofloxacinf })\end{array}$ \\
\hline Burkholderia pseudomallei & Carbapenem, ceftazidime & Fluoroquinolone, TMP-SMX \\
\hline Acinetobacter spp & Carbapenem & $\begin{array}{l}\text { Cephalosporin- } \\
\text { aminoglycoside, ampicillin- } \\
\text { sulbactam, colistin }\end{array}$ \\
\hline
\end{tabular}




\begin{tabular}{|c|c|c|}
\hline $\begin{array}{l}\text { Table } 3 \\
\text { (continued) }\end{array}$ & & \\
\hline Organism & Preferred Antimicrobial(s) & Alternative Antimicrobial(s) \\
\hline \multicolumn{3}{|l|}{ Staphylococcus aureus } \\
\hline Methicillin-susceptible & Antistaphylococcal penicilling & Cefazolin, clindamycin \\
\hline Methicillin-resistant & Vancomycin or linezolid & TMP-SMX \\
\hline Bordetella pertussis & Macrolide & TMP-SMX \\
\hline Anaerobe (aspiration) & $\begin{array}{l}\beta \text {-Lactam } / \beta \text {-lactamase } \\
\text { inhibitor, }{ }^{\mathbf{d}} \text { clindamycin }\end{array}$ & Carbapenem \\
\hline Influenza virus & Oseltamivir or zanamivir & \\
\hline Mycobacterium tuberculosis & $\begin{array}{l}\text { Isoniazid plus rifampin plus } \\
\text { ethambutol plus } \\
\text { pyrazinamide }\end{array}$ & $\begin{array}{l}\text { Refer to Ref. }{ }^{57} \text { for specific } \\
\text { recommendations }\end{array}$ \\
\hline Coccidioides spp & $\begin{array}{l}\text { For uncomplicated infection in } \\
\text { a normal host, no therapy } \\
\text { generally recommended; } \\
\text { for therapy, itraconazole, } \\
\text { fluconazole }\end{array}$ & Amphotericin B \\
\hline Histoplasmosis & Itraconazole & Amphotericin B \\
\hline Blastomycosis & Itraconazole & Amphotericin B \\
\hline
\end{tabular}

Choices should be modified based on susceptibility test results and advice from local specialists. Refer to local references for appropriate doses.

Abbreviations: MIC, minimum inhibitory concentration; TMP-SMX, trimethoprim-sulfamethoxazole.

a Levofloxacin, moxifloxacin, gemifloxacin (not a first-line choice for penicillin susceptible strains); ciprofloxacin is appropriate for Legionella and most gram-negative bacilli (including $\mathrm{H}$ influenza).

b Azithromycin is more active in vitro than clarithromycin for $H$ influenza.

c Imipenem-cilastatin, meropenem, ertapenem.

d Piperacillin-tazobactam for gram-negative bacilli; ticarcillin-clavulanate, ampicillin-sulbactam, or amoxicillinclavulanate.

e Ticarcillin, piperacillin, ceftazidime, cefepime, aztreonam, imipenem, meropenem.

f $750 \mathrm{mg} / \mathrm{d}$.

9 Nafcillin, oxacillin flucloxacillin.

From Mandell LA, Wunderink RG, Anzueto A, et al. Infectious Diseases Society of America/American Thoracic Society consensus guidelines on the management of community-acquired pneumonia in adults. Clin Infect Dis 2007;44:S27-72; with permission.

infection score, facilitation of weaning, and use of systemic antibiotics. ${ }^{64,66,67}$ A summary of microbiologic response to aerosolized antibiotics in recent studies is provided in Table 8.

With proper delivery, antimicrobial therapy may be targeted directly at the site of infection, increasing concentrations in the lung while minimizing systemic toxicity (Table 9). ${ }^{64}$ Delivery mechanisms range from atomizers to jet and ultrasonic nebulizers, and vibrating mesh technology. Given the rise in incidence of DRPs in the ICU, large multicenter trials are needed to validate these novel treatment options. The current guidelines from the American Thoracic Society do not recommend routine use of aerosolized antibiotic therapy but do state that aerosolized antibiotics may be considered for treatment of microorganisms with a high minimum inhibitory concentration to parenteral antibiotics. ${ }^{23}$

\section{MYCOBACTERIAL INFECTION}

Mycobacterial infection may manifest clinically with vast variation. Pulmonary infection is common and may be diagnostically challenging because of significant overlap in presenting symptoms with other pulmonary infections. Therefore, diagnosis is often delayed until confirmation with an invasive procedure, such as transbronchial biopsy, transthoracic needle biopsy, or surgical lung biopsy. ${ }^{69,70}$ Direct acid-fast bacillus smears of respiratory specimens are negative in approximately $50 \%$ of cases, ${ }^{71}$ and a biopsy may be the first suggestion of a mycobacterial infection (Fig. 16). ${ }^{72}$ Mycobacterial species can be categorized into two clinically relevant groups: Mycobacterium tuberculosis complex and nontuberculous mycobacteria (NTM).

$M$ tuberculosis is the most virulent mycobacterial species and is the etiologic agent of 
Table 4

Initial empiric therapy for HAP, VAP, and HCAP in patients with late-onset disease or risk factors for multidrug-resistant pathogens and all disease severity

\section{Potential Pathogens}

Pathogens listed in Table 2

and MDR pathogens

Pseudomonas aeruginosa

Klebsiella pneumoniae $(\mathrm{ESBL}+)^{\mathbf{b}}$

Acinetobacter spp ${ }^{b}$

\section{Combination Antibiotic Therapy ${ }^{a}$}

Antipseudomonal cephalosporin (cefepime, ceftazidime)

or

Antipseudomonal carbapenem (imipenem or meropenem)

or

$\beta$-Lactam/ $\beta$-lactamase inhibitor (piperacillin-tazobactam) plus

Antipseudomonal fluoroquinolone ${ }^{b}$ (ciprofloxacin or levofloxacin) or

Aminoglycoside (amikacin, gentamicin, or tobramycin)

\section{MRSA}

plus

Legionella pneumophilab

Abbreviation: ESBL, extended-spectrum $\beta$-lactamase.

a Initial antibiotic therapy should be adjusted or streamlined based on microbiologic data and clinical response to therapy.

b If an $\mathrm{ESBL}^{+}$strain, such as $K$ pneumoniae or an Acinetobacter sp is suspected, a carbapenem is a reliable choice. If $L$ pneumophila is suspected, the combination antibiotic regimen should include a macrolide (eg, azithromycin) or a fluoroquinolone (eg, ciprofloxacin or levofloxacin) should be used rather than an aminoglycoside.

c If MRSA risk factors are present or there is a high incidence locally.

Reprinted with permission of the American Thoracic Society. Copyright (c) 2012 American Thoracic Society. Guidelines for the management of adults with hospital-acquired, ventilator-associated, and healthcare-associated pneumonia. Am J Respir Crit Care Med 2005;171:388-416. Official journal of the American Thoracic Society.

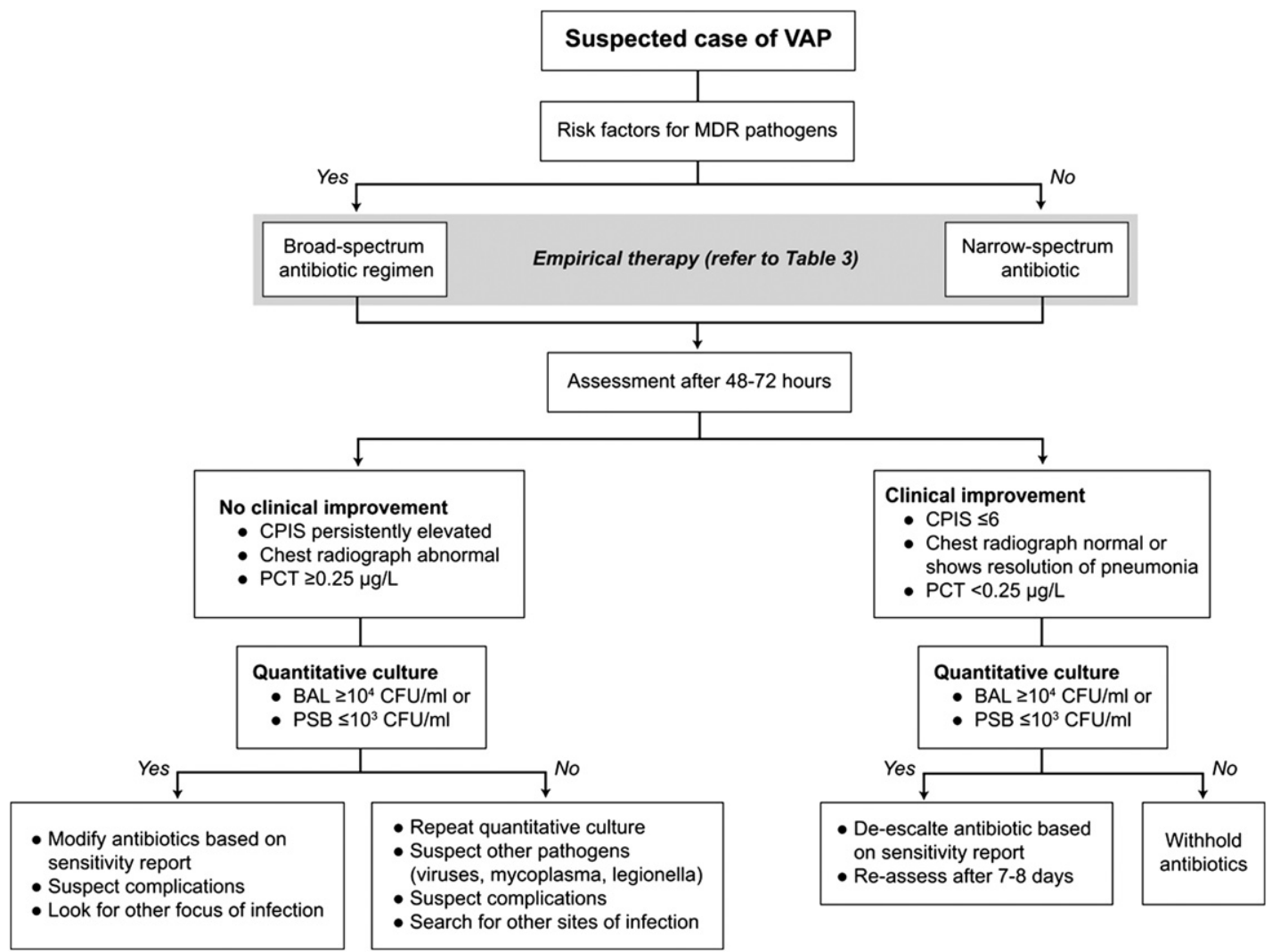

Fig. 15. Algorithm for treatment of VAP. BAL, bronchoalveolar lavage; CPIS, clinical pulmonary infection score; MDR, multi-drug resistant; PCT, procalcitonin; PSB, protected specimen brush. (From Joseph NM, Sistla S, Dutta TK, et al. Ventilator-associated pneumonia: a review. Eur J Inter Med 2010;21:360; with permission.) 


\begin{tabular}{|c|c|}
\hline $\begin{array}{l}\text { Table } 5 \\
\text { Risk factors for VAP }\end{array}$ & \\
\hline Host Factors & Intervention Factors \\
\hline $\begin{array}{c}\text { Oropharyngeal } \\
\text { colonization }\end{array}$ & $\begin{array}{l}\text { Emergency } \\
\text { intubation }\end{array}$ \\
\hline Gastric colonization & Reintubation \\
\hline $\begin{array}{l}\text { Thermal injury } \\
\text { (burns) }\end{array}$ & Tracheostomy \\
\hline Posttraumatic & Bronchoscopy \\
\hline Postsurgical & Nasogastric tube \\
\hline $\begin{array}{l}\text { Impaired } \\
\text { consciousness }\end{array}$ & $\begin{array}{l}\text { Duration of hospital } \\
\text { stay/ICU stay }\end{array}$ \\
\hline Immunosuppression & $\begin{array}{l}\text { Multiple central } \\
\text { venous line } \\
\text { insertions }\end{array}$ \\
\hline Organ failure & Sedatives \\
\hline Sinusitis & $\begin{array}{l}\text { Stress ulcer } \\
\text { prophylaxis }\end{array}$ \\
\hline $\begin{array}{l}\text { Severity of } \\
\text { underlying } \\
\text { illness } \\
\end{array}$ & $\begin{array}{l}\text { Prior antibiotics/no } \\
\text { antibiotic } \\
\text { prophylaxis }\end{array}$ \\
\hline Old age ( $\geq 60 \mathrm{y}$ ) & $\begin{array}{c}\text { Immunosuppressives } \\
\text { (corticosteroids) }\end{array}$ \\
\hline $\begin{array}{l}\text { Presence of } \\
\text { comorbidities }\end{array}$ & Supine head position \\
\hline
\end{tabular}

From Joseph NM, Sistla S, Dutta TK, et al. Ventilatorassociated pneumonia: a review. Eur J Intern Med 2010;21:360-8; with permission.

tuberculosis worldwide in its various forms. This organism is responsible for more deaths worldwide than any other single microbe. Postprimary tuberculosis, the most common form in adults, typically involves the apices of the upper lobes, producing granulomatous lesions with cavities and variable degrees of fibrosis and retraction of the parenchyma. ${ }^{73-75}$ In a minority of patients, the lesions enlarge and progress secondary to increased necrosis and/or liquefaction. ${ }^{76}$

NTM include more than 125 species $^{77,78}$; however, relatively few cause pulmonary disease. ${ }^{72,79-81}$ NTM species are subdivided according to growth rates. Of the rapid growers, $M$ abscessus is the most frequently recovered pulmonary pathogen, whereas $M$ fortuitum and $M$ chelonae are more often associated with wound infection and soft tissue disease. ${ }^{68}$ Among the slow growers, $M$ avium-intracellulare complex is the most common NTM respiratory pathogen, followed by $M$ kansasii in the United States and $M$ xenopi in Europe. NTM may cause a wide spectrum of pulmonary and extrapulmonary disease, but most frequently cause fibronodular bronchiectasis or cavitation. ${ }^{68}$

\begin{tabular}{|c|c|}
\hline Common Causes & Rare/Unusual Causes \\
\hline Gram-positive cocci & Gram-positive bacilli \\
\hline $\begin{array}{l}\text { Staphylococcus } \\
\text { aureus }\end{array}$ & $\begin{array}{l}\text { Corynebacterium } \\
\text { spp (diphtheroids) }\end{array}$ \\
\hline $\begin{array}{l}\text { Streptococcus } \\
\text { pneumoniae }\end{array}$ & $\begin{array}{l}\text { Listeria } \\
\quad \text { monocytogenes } \\
\end{array}$ \\
\hline Other streptococci & Nocardia spp \\
\hline $\begin{array}{l}\text { Coagulase-negative } \\
\text { staphylococci }\end{array}$ & $\begin{array}{l}\text { Aerobic gram- } \\
\text { negative bacilli }\end{array}$ \\
\hline Enterococci & Serratia spp \\
\hline $\begin{array}{l}\text { Aerobic gram- } \\
\text { negative bacilli }\end{array}$ & Hafnia alvei \\
\hline $\begin{array}{l}\text { Enteric gram- } \\
\text { negative bacilli }\end{array}$ & $\begin{array}{l}\text { Stenotrophomonas } \\
\text { maltophilia }\end{array}$ \\
\hline Escherichia coli & $\begin{array}{l}\text { Burkholderia } \\
\text { cepacia }\end{array}$ \\
\hline Klebsiella spp & Gram-negative cocci \\
\hline Enterobacter spp & Neisseria spp \\
\hline Proteus spp & Moraxella spp \\
\hline Citrobacter spp & Anaerobic bacteria \\
\hline Nonfermentative & Bacilli \\
\hline $\begin{array}{l}\text { Gram-negative } \\
\text { bacilli }\end{array}$ & Bacteroides spp \\
\hline Pseudomonas spp & $\begin{array}{l}\text { Fusobacterium } \\
\text { spp }\end{array}$ \\
\hline Acinetobacter spp & Prevotella spp \\
\hline $\begin{array}{l}\text { Haemophilus } \\
\text { influenzae }\end{array}$ & Actinomyces spp \\
\hline Fungi & Cocci \\
\hline Candida spp & $\begin{array}{c}\text { Veillonella spp } \\
\text { Peptostreptococci } \\
\text { Atypical bacteria } \\
\text { Legionella spp } \\
\text { Mycoplasma } \\
\text { pneumoniae } \\
\text { Chlamydia } \\
\text { pneumoniae } \\
\text { Fungi } \\
\text { Aspergillus spp and } \\
\text { other molds } \\
\text { Pneumocystis } \\
\text { jiroveci } \\
\text { Viruses } \\
\text { Influenza and other } \\
\text { respiratory viruses } \\
\text { Herpes simplex virus } \\
\text { Cytomegalovirus } \\
\text { Miscellaneous causes } \\
\text { Mycobacterium } \\
\text { tuberculosis } \\
\end{array}$ \\
\hline
\end{tabular}

From Joseph NM, Sistla S, Dutta TK, et al. Ventilatorassociated pneumonia: a review. Eur J Intern Med 2010;21:360-8; with permission. 


\begin{tabular}{|c|c|}
\hline $\begin{array}{l}\text { VAP With No Risk } \\
\text { Factors for MDR } \\
\text { Pathogens }\end{array}$ & $\begin{array}{l}\text { VAP With Risk Factors } \\
\text { for MDR Pathogens }\end{array}$ \\
\hline $\begin{array}{l}\text { Ceftriaxone } \\
\text { or } \\
\text { Levofloxacin, } \\
\quad \text { moxifloxacin, or } \\
\text { ciprofloxacin } \\
\text { or } \\
\text { Ampicillin/sulbactam } \\
\text { or } \\
\text { Ertapenem }\end{array}$ & $\begin{array}{l}\text { Antipseudomonal } \\
\text { cephalosporin } \\
\text { (cefepime, } \\
\text { ceftazidime) } \\
\text { or } \\
\text { Antipseudomonal } \\
\text { carbapenem } \\
\text { (imipenem or } \\
\text { meropenem) } \\
\text { or } \\
\beta \text {-Lactam/ } \beta \text {-lactamase } \\
\text { inhibitor } \\
\text { (piperacillin- } \\
\text { tazobactam) } \\
\text { plus } \\
\text { Antipseudomonal } \\
\text { fluoroquinolone } \\
\text { (ciprofloxacin or } \\
\text { levofloxacin) } \\
\text { or } \\
\text { Aminoglycoside } \\
\text { (amikacin, } \\
\text { gentamicin, } \\
\text { or tobramycin) } \\
\text { plus } \\
\text { Linezolid or } \\
\text { vancomycin (if risk } \\
\text { factors for MRSA are } \\
\text { present) }\end{array}$ \\
\hline
\end{tabular}

From Joseph NM, Sistla S, Dutta TK, et al. Ventilatorassociated pneumonia: a review. Eur J Intern Med 2010;21:360-8; with permission.

\section{Treatment of Mycobacterial Pulmonary Infection}

Treatment of mycobacterial disease is generally more complicated than that for other bacteria because of the slow growth of the organisms, mechanisms of drug resistance (eg, the unique cell wall characteristics of the genus), and poor drug tolerability. Multidrug regimens are required for extended duration. Once the diagnosis of active pulmonary tuberculosis is confirmed, initial recommended treatment comprises a four-drug regimen of isoniazid, rifampin, pyrazinamide, and either ethambutol or streptomycin, according to local patterns of susceptibility. ${ }^{82}$ Duration of therapy depends on the drug susceptibility of the isolate, presence of extrapulmonary involvement, and immune status of the patient. Although acquired resistance does occur, the more common cause of treatment failure is medication

\begin{abstract}
Box 3
Aerosolized antibiotics described in the literature: off-label use and U.S. Food and Drug Administration-approved drugs

Cystic fibrosis

Gentamicin

Amikacin

Tobramycin $^{a}$

Aztreonam lysine ${ }^{b}$

Liposomal amikacin ${ }^{c}$

Mechanically ventilated patients

Sisomicin

Gentamicin

Amikacin

Cefuroxime/ceftazidime

Colistin-polymyxin B

Vancomycin

Amikacin proprietary preparation ${ }^{d}$

a U.S. Food and Drug Administration (FDA)-approved medication for maintenance therapy for patients with cystic fibrosis who are known to be colonized with $P$ aeruginosa; tobramycin (Tobi, PARI Pharma GmbH, Weilheim, Germany) delivered with PARI LC Plus nebulizer or Pulmo-Aide compressor.

b FDA-approved medication for patients with cystic fibrosis for more than 7 years with chronic Pseudomonas infection; aztreonam (Cayston inhalation, PARI Pharma GmbH, Weilheim, Germany) delivery with Altera Nebulizer System using eflow.

c Phase 2 completed. For patients with cystic fibrosis with Pseudomonas infections; liposomal amikacin (Arikace, PARI Pharma GmbH, Weilheim, Germany).

d Phase 2 trial completed. Aerosol amikacin, Bayer Healthcare. Delivered with Nektar Therapeutics LPT.

From Palmer LB. Aerosolized antibiotics in the intensive care unit. Clin Chest Med 2011;32:559-74; with permission.
\end{abstract}

nonadherence. For this reason, evidence strongly supports direct observational therapy. Confirmation of clearance of sputum acid-fast bacilli is recommended at 3 months.

Given the increase in MDR and extensively drug-resistant $M$ tuberculosis strains, repeat susceptibility testing is warranted with documented treatment failure. If drug-resistant strains are identified, expert consultation is recommended, and a regimen composed of at least four agents should be selected in a stepwise approach from the following classes: (1) all first-line agents to which the strain is sensitive: isoniazid, rifampin, pyrazinamide, and ethambutol; (2) one fluoroquinolone, if susceptible; (3) one injectable aminoglycoside, such as streptomycin or kanamycin; 


\begin{tabular}{|c|c|c|c|c|c|c|c|c|c|c|}
\hline \multicolumn{11}{|c|}{$\begin{array}{l}\text { Table } 8 \\
\text { Microbiological response to aerosolized antibiotics }\end{array}$} \\
\hline Authors & Year & Setting & Design & Indication & $\begin{array}{l}\text { Method of } \\
\text { Aerosolization; } \\
\text { Drug }\end{array}$ & No of Patients & $\begin{array}{l}\text { No of Patients } \\
\text { on Systemic } \\
\text { Antibiotic Use }\end{array}$ & $\begin{array}{l}\text { No of Organisms } \\
\text { in Patients }\end{array}$ & $\begin{array}{l}\text { No of Patients } \\
\text { with Eradication of } \\
\text { Causative Organism }\end{array}$ & $\begin{array}{l}\text { No of Patients } \\
\text { with Resistant } \\
\text { Organisms } \\
\end{array}$ \\
\hline $\begin{array}{l}\text { Michalopoulos } \\
\text { et al }\left.\right|^{117}\end{array}$ & 2005 & $\begin{array}{l}\mathrm{ICU}, \\
\text { Greece }\end{array}$ & $\begin{array}{l}\text { Retrospective } \\
\text { chart review }\end{array}$ & $\begin{array}{l}\text { VAP for } \\
6 \text { patients, } \\
\text { HAP for } \\
2 \text { patients }\end{array}$ & $\begin{array}{l}\text { Aerosolized via } \\
\text { Siemens } \\
\text { Servo Ventilator; } \\
\text { colistin }\end{array}$ & 8 & $7 / 8$ & $\begin{array}{l}\text { Acinetobacter, } 7 \\
\quad \text { Pseudomonas, } 1\end{array}$ & $4 / 5$ & None \\
\hline $\begin{array}{l}\text { Kwa } \\
\text { et al }{ }^{118}\end{array}$ & 2005 & $\begin{array}{l}\mathrm{ICU}, \\
\text { Singapore }\end{array}$ & $\begin{array}{l}\text { Retrospective } \\
\text { chart review }\end{array}$ & VAP & $\begin{array}{l}\text { Aerosolized } \\
\text { colistin; } \\
\text { no data on } \\
\text { method } \\
\end{array}$ & 21 & $\begin{array}{l}\text { Yes, but not } \\
\text { active against } \\
\text { causative } \\
\text { organism } \\
\end{array}$ & $\begin{array}{l}\text { Acinetobacter, 17; } \\
\text { Pseudomonas, } 4\end{array}$ & $\begin{array}{l}\text { 11/11 available } \\
\text { cultures }\end{array}$ & Not described \\
\hline $\begin{array}{l}\text { Berlana } \\
\quad \text { et al }{ }^{119}\end{array}$ & 2005 & ICU, Spain & $\begin{array}{l}\text { Retrospective } \\
\text { chart review }\end{array}$ & $\begin{array}{l}\text { Pulmonary } \\
\text { infection }\end{array}$ & $\begin{array}{l}\text { Aerosolized with } \\
\text { various } \\
\text { compressors; } \\
\text { colistin } \\
\end{array}$ & 71 & $\begin{array}{l}78 \% \text { of } \\
\text { patients }\end{array}$ & $\begin{array}{l}\text { Acinetobacter, 60; } \\
\quad \text { Pseudomonas, } 11\end{array}$ & $\begin{array}{l}\text { Acinetobacter, 33/33; } \\
\text { Pseudomonas, } 4 / 7\end{array}$ & Not described \\
\hline $\begin{array}{l}\text { Michalopoulos } \\
\text { et al }{ }^{120}\end{array}$ & 2008 & ICU, Greece & Prospective & VAP & $\begin{array}{l}\text { Aerosolized via } \\
\text { Siemens Servo } \\
\text { Ventilator; } \\
\text { colistin } \\
\end{array}$ & 60 & 57 & $\begin{array}{l}\text { Acinetobacter, 37; } \\
\text { Pseudomonas, 12; } \\
\text { Klebsiella, } 11\end{array}$ & $50 / 60$ & Not described \\
\hline $\begin{array}{l}\text { Palmer } \\
\quad \text { et al }{ }^{65}\end{array}$ & 2008 & $\begin{array}{l}\text { ICU, United } \\
\text { States }\end{array}$ & $\begin{array}{l}\text { Randomized, } \\
\text { double-blind, } \\
\text { placebo- } \\
\text { controlled }\end{array}$ & $\begin{array}{l}\text { VAT } \geq 2 \mathrm{~mL} \text { sputum } \\
\text { produced over } \\
4 \mathrm{~h} \text { and organisms } \\
\text { on Gram stain }\end{array}$ & $\begin{array}{l}\text { AeroTech jet } \\
\text { nebulizer; } \\
\text { vancomycin } \\
\text { and/or } \\
\text { gentamicin } \\
\end{array}$ & $\begin{array}{l}\text { 24, placebo; } \\
\text { 19, AA }\end{array}$ & $32 / 43$ & $\begin{array}{l}\text { Multiple species of } \\
\text { gram-negative and } \\
\text { gram-positive } \\
\text { organisms }\end{array}$ & $\begin{array}{l}\text { Placebo, } 19 ; \\
\quad \text { aerosolized, } 17\end{array}$ & $\begin{array}{c}\text { Placebo (8/24), } \\
\text { AA (0/19) }\end{array}$ \\
\hline $\begin{array}{l}\text { Kofteridis } \\
\text { et al }^{121}\end{array}$ & 2010 & ICU, Greece & $\begin{array}{l}\text { Retrospective } \\
\text { review, matched } \\
\text { case control }\end{array}$ & VAP & $\begin{array}{l}\text { Aerosolized } \\
\text { colistin; } \\
\text { no details on } \\
\text { method } \\
\end{array}$ & $\begin{array}{l}43 \text { IV and } \\
\text { aerosolized } \\
\text { colistin; } \\
43 \text { IV colistin }\end{array}$ & All patients & $\begin{array}{l}\text { Acinetobacter, 66; } \\
\text { Klebsiella, 12; } \\
\text { Pseudomonas, } 8\end{array}$ & $\begin{array}{l}\text { Placebo, } 17(50 \%) \\
\text { aerosolized, } \\
19(45 \%)\end{array}$ & Not described \\
\hline $\begin{array}{l}\text { Korbila } \\
\quad \text { et al }{ }^{122}\end{array}$ & 2010 & ICU, Greece & $\begin{array}{l}\text { Retrospective } \\
\text { review, matched } \\
\text { case control }\end{array}$ & VAP & $\begin{array}{l}\text { Aerosolized via } \\
\text { Siemens } \\
\text { Servo Ventilator; } \\
\text { colistin }\end{array}$ & $\begin{array}{l}43 \text { IV colistin; } \\
78 \text { aerosolized } \\
\text { and IV colistin }\end{array}$ & All patients & $\begin{array}{l}\text { MDR gram-negative } \\
\text { organisms }\end{array}$ & $\begin{array}{l}\text { Placebo, } \\
26(60.5 \%) ; \\
\text { aerosolized, } \\
62(79.5 \%) \\
\end{array}$ & Not described \\
\hline
\end{tabular}

Abbreviations: AA, aerosolized antibiotic; IV, intravenous; VAT, ventilator-associated tracheobronchitis.

From Palmer LB. Aerosolized antibiotics in the intensive care unit. Clin Chest Med 2011;32:559-74; with permission. 


\begin{tabular}{|l}
\hline $\begin{array}{l}\text { Table } \mathbf{9} \\
\text { Toxicity related to aerosolized antibiotics }\end{array}$ \\
\begin{tabular}{ll} 
Drug & Adverse Effects \\
\hline Aminoglycosides & Bronchial constriction, renal toxicity, ${ }^{\text {a }}$ tinnitus, vestibular toxicity, hoarseness \\
\hline Colistin & Nephrotoxicity, ${ }^{\mathbf{b}}$ bronchospasm, ${ }^{\mathbf{b}}$ neurologic toxicity \\
\hline Aztreonam lysine & Cough, bronchoconstriction \\
\hline Vancomycin & Not well described \\
\hline Cefotaxime/ceftazidime & Not well described \\
\hline
\end{tabular}
\end{tabular}

a Renal toxicity rarely seen with tobramycin (Tobi, RARI Pharma GmbH, Weilheim, Germany).

b Nephrotoxicity and bronchospasm more severe than with aminoglycosides.

From Palmer LB. Aerosolized antibiotics in the intensive care unit. Clin Chest Med 2011;32:559-74; with permission.

(4) less effective second-line antituberculous drugs, such as ethionamide or cycloserine; and (5) second-line agents for which few data are available: linezolid, clarithromycin, amoxicillinclavulanate, or clofazamine. ${ }^{83}$

Treatment of pulmonary NTM is less well defined. Although the principles of management are similar to those for $M$ tuberculosis, antibiotic regimens vary by species. ${ }^{68}$ For $M$ avium complex, ATS/IDSA guidelines recommend a combination of clarithromycin, rifampicin, and ethambutol, whereas for $M$ kansasii, the initial regimen comprises isoniazid, rifampicin, and ethambutol. ${ }^{72}$ For localized pulmonary $M$ abscessus infection, medical management alone is not effective and surgical resection is required.

\section{Hemoptysis}

Tuberculosis remains the most common cause of hemoptysis worldwide; however, in the United States, invasive fungal infections, chronic

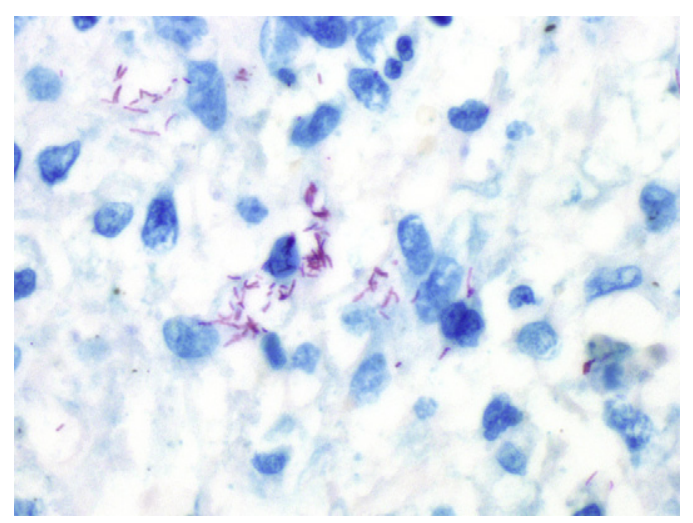

Fig. 16. Histiocytic exudate with many mycobacteria (red) in this mycobacterial pneumonia. The relatively large number of organisms seen here and the loose appearance of the histiocytes together suggests an immunocompromised host. Fite mycobacterial stain, original magnification, $\times 600$. granulomatous disease, bronchiectasis, and bronchitis account for most cases. ${ }^{84,85}$ Conservative management can often control bleeding. The current recommended strategy for hemoptysis is initial nonoperative management and stabilization, with surgery reserved for isolated cases. ${ }^{86-88}$ For a patient presenting with massive hemoptysis, the immediate goals of the surgeon are to preserve life through protecting the healthy lung from aspiration, to stabilize the patient hemodynamically, and to correct any coagulopathy. ${ }^{85}$ Bronchoscopy can often be effective if bleeding is mild. ${ }^{89}$

More than $80 \%$ of patients can be treated successfully with bronchoscopic localization. ${ }^{84,89}$ The bleeding site can be controlled with balloon tamponade, laser ablation, and local vasopressor therapy. The decision to intervene angiographically should be made based on the clinical examination, imaging results, bronchoscopic findings, and physician expertise. Transcatheter arterial embolization is successful in most patients. ${ }^{84,85,90-94}$ Although bronchial embolization is the mainstay of treatment, emergency surgery can be considered if initial attempts to control bleeding and stabilize the patient prove unsuccessful. The decision to take the patient to the operating room requires at a minimum known laterality of the lesion and, optimally, lobar location (Fig. 17). ${ }^{85}$

\section{INVASIVE FUNGAL PULMONARY INFECTION}

With the rapid increase in bone marrow and solid organ transplantation, invasive fungal infection has become a significant cause of morbidity and mortality. Although nearly 100 fungi have been recovered from respiratory infections, ${ }^{95}$ only a small number are consistently implicated as pathogenic (Box 4). Broadly, fungal pathogens that infect the lung include yeasts such as Candida spp and Cryptococcus; endemic dimorphic fungi such as Histoplasma and Coccidioides; filamentous molds, of which Aspergillus is most 


\section{Management of Hemoptysis}

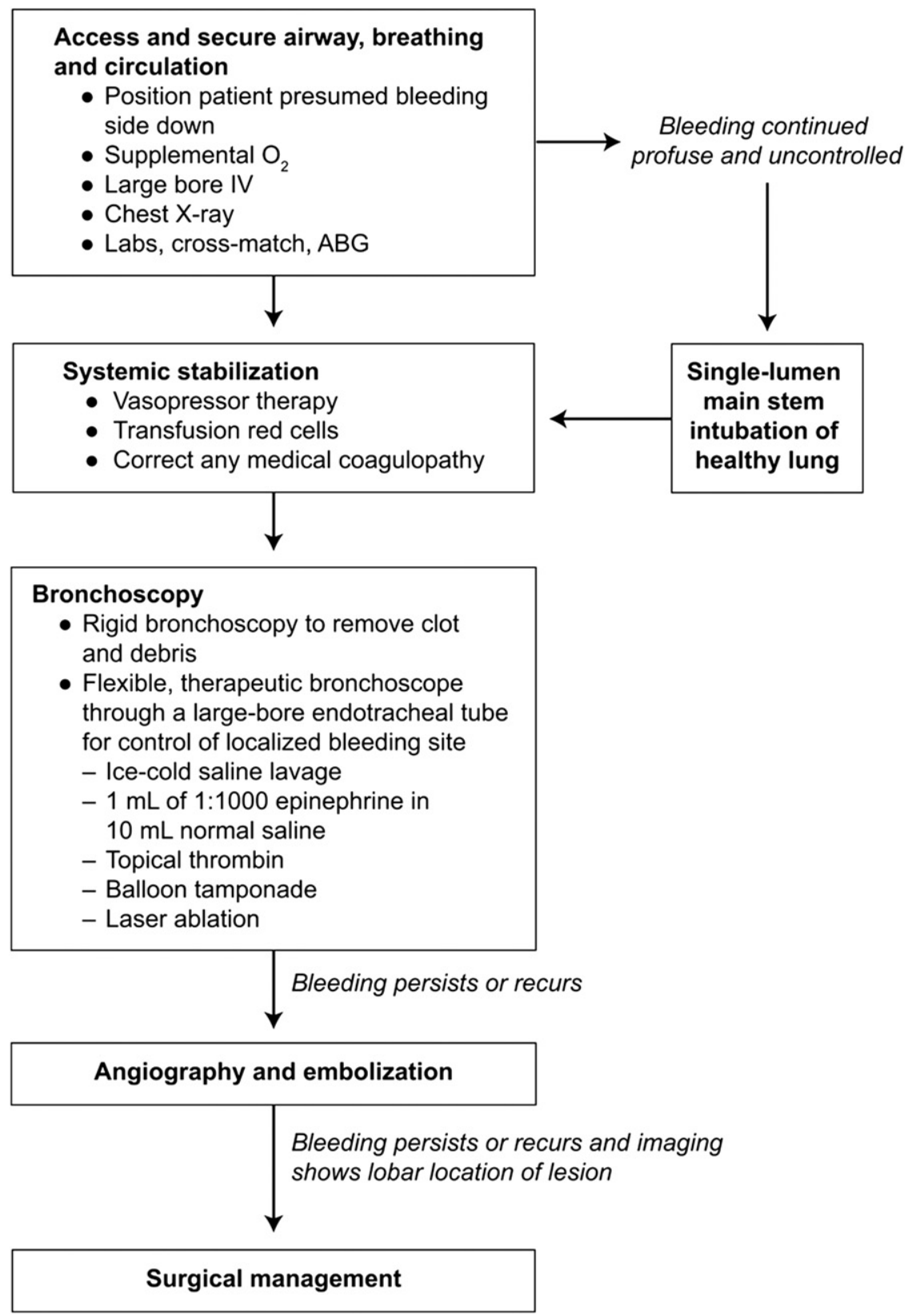

Fig. 17. Algorithm for management of hemoptysis. BG, arterial blood gas.

common; and members of the family Mucorales. The most effective method of diagnosis is often identification of fungi in tissue sections or cytologic samples (Fig. 18). ${ }^{31,96,97}$

The patient may present with a wide spectrum of radiographic pulmonary disease. In the healthy host, fungal pathogens typically produce one or more nodular lesions (Fig. 19), which, in turn, may become cavitary as the lesions evolve (Fig. 20). However, clinical presentation may vary widely and may include solitary or multiple and bilateral nodular lesions; segmental or lobar consolidation; cavitary lesions, fistulas, infarcts; direct extension into mediastinal, thoracic soft tissue, chest wall, and diaphragm; chronic tracheal and endobronchial infection; and fungus 


\section{Box 4 \\ Common fungal pathogens in the lung}

Dimorphic fungi (mycelia at $25^{\circ} \mathrm{C}-30^{\circ} \mathrm{C}$; yeast at $\left.37^{\circ} \mathrm{C}\right)$

\section{Blastomyces dermatitidis}

Coccidioides immitis

Histoplasma capsulatum

Paracoccidioides braziliensis

Sporothrix schenckii

Penicillium marneffei

Yeasts

\section{Cryptococcus neoformans}

Candida spp

Hyaline (nonpigmented) molds

Aspergillus spp

Zygomycetes organisms

Phaeoid (pigmented; dematiaceous) molds

Bipolaris spp, Alternaria, Curvularia

Pseudoallescheria boydii/Scedosporium apiospermum

Miscellaneous pathogens

\section{Pneumocystis jiroveci}

Data from Rosati LA, Leslie KO. Lung infections. In: Leslie KO, Wick MR, editors. Practical pulmonary pathology: a diagnostic approach. Philadelphia: Elsevier/Saunders; 2011.

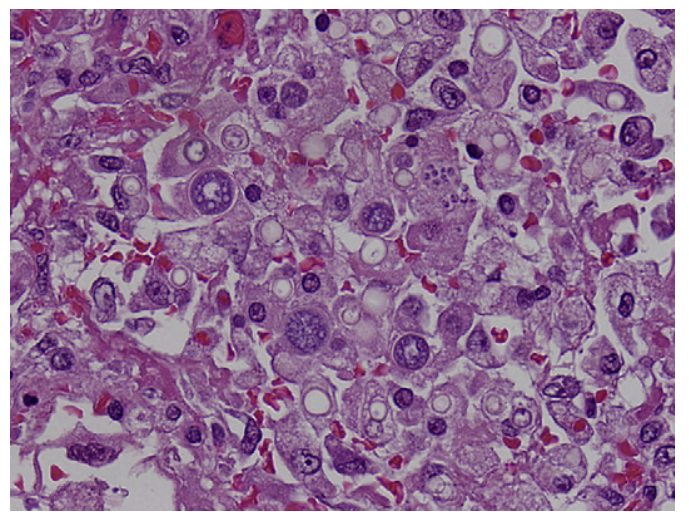

Fig. 18. Disseminated coccidioidomycosis with confluent spherules of Coccidioides immitus. Each spherule has a thick refractile wall and contains numerous tiny endospores. Spherules enlarge and eventually burst, so many sizes are present typically, some of which may be ruptured and empty. Hematoxylin and eosin stain, original magnification, $\times 200$.

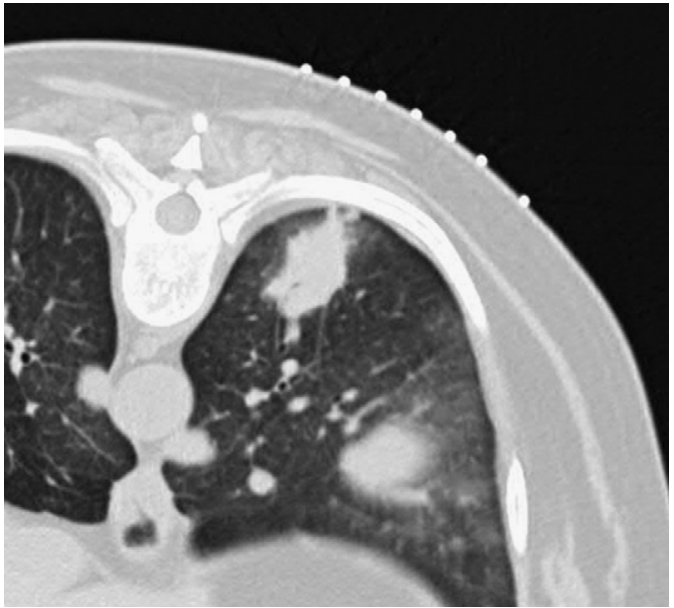

Fig. 19. CT scan shows multiple nodules in patient's lung subsequently shown to be infection with Coccidioidomycosis.

ball such as aspergilloma. ${ }^{98}$ Proximal endobronchial disease mimicking a neoplasm has also been described for various fungal species. ${ }^{99}$

\section{Treatment of Fungal Infection}

Until recently, effective treatment options for invasive fungal infection were largely limited to amphotericin B deoxycholate, which is well known for its potential for systemic toxicity. However, the development of lipid, liposomal, and aerosolized formulations of amphotericin B, and newer triazole and echinocandin antifungal agents, has greatly expanded treatment options for these diseases. Because of differences in antifungal susceptibility and prognosis between dimorphic endemic fungi, filamentous fungi, and other molds (eg, Mucor), a definitive microbiologic or pathologic diagnosis is strongly preferred before treatment.

For invasive Aspergillus infection, a large randomized controlled trial showed the superiority of voriconazole over amphotericin $\mathrm{B},{ }^{100}$ and now voriconazole is recommended as the primary

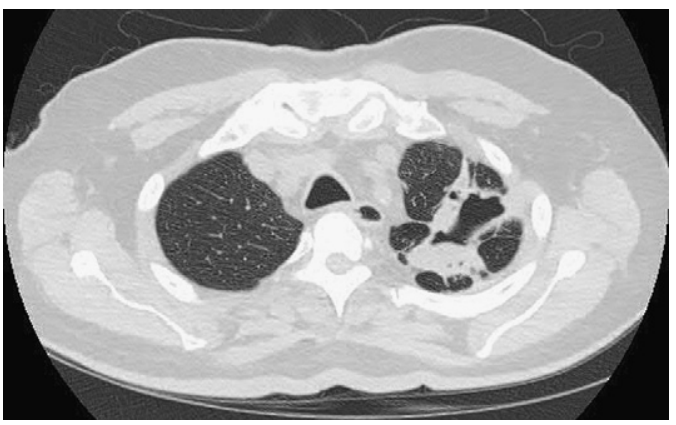

Fig. 20. CT scan shows invasive Aspergilloma fungal ball in the left lower lobe. 
treatment of invasive pulmonary aspergillosis in most patients. ${ }^{101}$ Limited data suggest that in certain populations, such as heart transplant recipients, voriconazole in combination therapy with caspofungin may contribute to improved outcomes; additional data are anticipated. ${ }^{102,103}$ In lung transplant recipients, aerosolized amphoteri$\operatorname{cin} B$ has been used for antifungal prophylaxis and as adjunct therapy in invasive fungal disease. ${ }^{104}$

In pulmonary mucormycosis, however, voriconazole is ineffective. The preferred treatment remains amphotericin B, although some data suggest that liposomal amphotericin B may be more efficacious than the deoxycholate formulation. ${ }^{105} \mathrm{~A}$ novel triazole, posaconazole, has also been approved for salvage therapy, but it is limited by its availability in oral formulation only and its inconsistent bioavailability. ${ }^{105}$ Limited evidence also suggests improved outcomes with a combination therapy of amphotericin B and posaconazole or an echinocandin. ${ }^{105}$ When empiric therapy is required in critically ill patients in whom hemodynamic instability or cytopenia may prevent invasive diagnostic procedures, the logical approach is combination therapy with voriconazole and amphotericin B.

\section{VIRAL PNEUMONIA}

Viruses cause more infections in the respiratory tract than all other types of microorganisms combined. ${ }^{106}$ The viruses that commonly infect the lung are presented in Box 5. The common
Box 5

Viruses linked to CAP in children and adults

- Respiratory syncytial virus

- Rhinovirus

- Influenza A, B, and C viruses

- Human metapneumovirus

- Parainfluenza viruses types 1, 2, 3, and 4

- Human bocavirusa

- Coronavirus types 229E, OC43, NL63, HKU1, SARS

- Adenovirus

- Enteroviruses

- Varicella-zoster virus

- Hantavirus

- Parechoviruses

- Epstein-Barr virus

- Human herpesvirus 6 and 7

- Herpes simplex virus

- Mimivirus

- Cytomegalovirus ${ }^{b}$

- Measles ${ }^{\mathrm{b}}$

a Mostly in children.

b Mostly in developing countries.

Data from Ruuskanen O, Lahti E, Jennings LC, et al.

Viral pneumonia. Lancet 2011;377:1264-75.

\begin{tabular}{|c|c|c|}
\hline \multicolumn{3}{|c|}{$\begin{array}{l}\text { Table } 10 \\
\text { Possibilities for antiviral treatment and prevention of severe viral pneumonia }\end{array}$} \\
\hline & Treatment & Prevention \\
\hline Influenza $A$ and $B$ viruses & $\begin{array}{l}\text { Oseltamivir (oral); zanamivir } \\
\text { (inhalation, intravenous); } \\
\text { peramivir (intravenous) }\end{array}$ & $\begin{array}{l}\text { Vaccines (inactivated, live); } \\
\text { oseltamivir; zanamivir }\end{array}$ \\
\hline Influenza A virus & $\begin{array}{l}\text { Amantadine (oral); } \\
\text { rimantadine (oral) }\end{array}$ & $\begin{array}{l}\text { Vaccines (inactivated, live); } \\
\text { oseltamivir; zanamivir }\end{array}$ \\
\hline Respiratory syncytial virus & $\begin{array}{l}\text { Ribavirin (inhalation, } \\
\text { intravenous) }\end{array}$ & Palivizumab (intramuscular) \\
\hline Adenovirus & Cidofovir (intravenous) & Vaccine for types 4 and $7^{a}$ \\
\hline Rhinovirus & Pleconaril $^{\mathbf{b}}$ & Alfa interferon (intranasal) \\
\hline Enteroviruses & Pleconaril $^{\mathbf{b}}$ & Alfa interferon (intranasal) \\
\hline Human metapneumovirus & Ribavirin (intravenous) & Alfa interferon (intranasal) \\
\hline Hantavirus & Ribavirin (intravenous) & Alfa interferon (intranasal) \\
\hline Varicella-zoster virus & Acyclovir (intravenous) & Vaccine \\
\hline
\end{tabular}

a Long successful use in U.S. military conscripts, no production now.

b Has been used for compassionate cases.

Data from Ruuskanen O, Lahti E, Jennings LC, et al. Viral pneumonia. Lancet 2011;377:1264-75. 
respiratory viruses (eg, influenza, parainfluenza, respiratory syncytial virus, adenovirus) cause outbreaks of respiratory illness in the general population each year. Fortunately, most viral respiratory infections are mild and self-limited. However, viruses are also capable of producing serious or life-threatening infections, such as in the case of primary varicella-zoster pneumonia ${ }^{107}$ or respiratory disease caused by highly pathogenic strains of influenza. ${ }^{108,109}$ In addition, viralmediated bronchial epithelial damage predisposes susceptible patients to secondary bacterial infection, which is associated with significant morbidity and mortality. ${ }^{110}$ Recent outbreaks of the H1N1 strain of influenza A have served to highlight the increased risk of mortality associated with influenza complicated by secondary bacterial infection, especially with $S$ aureus. ${ }^{111,112}$

In immunocompromised hosts, less common viral agents may cause severe clinical disease. In these patients, diagnosis may be made through respiratory cytologic specimens, from which herpes simplex, Cytomegalovirus, and adenovirus are the most commonly identified viral pathogens. ${ }^{113}$ The cytologic features of viral infections in the respiratory tract are most likely to be found in exfoliative specimens, such as bronchial washings and bronchoalveolar lavage. ${ }^{114,115}$

\section{Treatment of Viral Pulmonary Infection}

In most respiratory infection caused by viruses, no treatment is necessary. No consensus exists on prophylactic antibiotic treatment of influenza-like illness. However, when secondary bacterial pneumonia is suspected, antibacterial agents targeting the most common causative pathogens (S pneumoniae and $S$ aureus, including MRSA) should be initiated. Treatment options for primary viral respiratory tract infections are limited. For influenza A, early treatment with oseltamivir or zanamivir within 48 hours of the onset of symptoms has been shown to decrease complications, especially in the very young, elderly individuals, and patients with impaired immune status or comorbid conditions. Table $10^{116}$ summarizes the possible for antiviral treatments for prevention of severe viral pneumonia.

\section{REFERENCES}

1. Chandler F. Approaches to the pathologic diagnosis of infectious diseases. In: Connor D, Chandler F, Schwartz D, et al, editors. Pathology of infectious disease, vol. 1. 1st edition. Stamford (CT): Appleton and Lange; 1997. p. 3.

2. Colby TV, Weiss RL. Current concepts in the surgical pathology of pulmonary infections. Am J Surg Pathol 1987;11(Suppl 1):25.
3. Dichter JR, Levine SJ, Shelhamer JH. Approach to the immunocompromised host with pulmonary symptoms. Hematol Oncol Clin North Am 1993;7: 887.

4. Dunn DL. Diagnosis and treatment of opportunistic infections in immunocompromised surgical patients. Am Surg 2000;66:117.

5. Levine SJ. An approach to the diagnosis of pulmonary infections in immunosuppressed patients. Semin Respir Infect 1992;7:81.

6. Travis WD. Surgical pathology of pulmonary infections. Semin Thorac Cardiovasc Surg 1995;7:62.

7. Wilson WR, Cockerill FR 3rd, Rosenow EC 3rd. Pulmonary disease in the immunocompromised host (2). Mayo Clin Proc 1985;60:610.

8. Khoor A, Leslie KO, Tazelaar HD, et al. Diffuse pulmonary disease caused by nontuberculous mycobacteria in immunocompetent people (hot tub lung). Am J Clin Pathol 2001;115:755.

9. Donowitz GR, Mandell GL. Acute pneumonia. In: Mandell GL, Bennett JE, Dolin R, editors. Principles and practice of infectious diseases, vol. 1. 5th edition. Philadelphia: Churchill Livingstone Elsevier; 2000. p. 717.

10. Burt ME, Flye W, Webber BL, et al. Prospective evaluation of aspiration needle, cutting needle, transbronchial and open lung biopsy in patients with pulmonary infiltrates. Ann Thorac Surg 1981;32:146.

11. Danes C, Gonzalez-Martin J, Pumarola T, et al. Pulmonary infiltrates in immunosuppressed patients: analysis of a diagnostic protocol. J Clin Microbiol 2002;40:2134.

12. Leslie K, Lanza L, Helmers R, et al. Diagnostic sampling of lung tissues and cells. In: Davis G, Marcey T, Seward E, editors. Medical management of pulmonary diseases. 1st edition. New York: Marcel Dekker; 1999. p. 213.

13. Muscedere J, DudekP, Keenan S, et al. Comprehensive evidence-based clinical practice guidelines for ventilator- associated pneumonia: diagnosis and treatment. J Crit Care 2008;23:132.

14. Popp W, Rauscher H, Ritschka L, et al. Diagnostic sensitivity of different techniques in the diagnosis of lung tumors with the flexible fiberoptic bronchoscope-comparison of brush biopsy, imprint cytology of forceps biopsy, and histology of forceps biopsy. Cancer 1991;67:72.

15. Rea-Neto A, Youssef N, Tuche F, et al. Diagnosis of ventilator-associated pneumonia: a systematic review of the literature. Crit Care 2008;12:R56.

16. Yang $P$, Lee $Y, Y u C$, et al. Ultrasonographically guided biopsy of thoracic tumors - a comparison of large-bore cutting biopsy with fine-needle aspiration. Cancer 1992;69:2553.

17. Zavala D. Diagnostic fiberoptic bronchoscopy: techniques and results of biopsy in 600 patients. Chest 1975;68:12 
18. Joos L, Patuto N, Chhajed PN, et al. Diagnostic yield of flexible bronchoscopy in current clinical practice. Swiss Med Wkly 2006;136:155.

19. Kovnat DM, Rath GS, Anderson WM, et al. Maximal extent of visualization of bronchial tree by flexible fiberoptic bronchoscopy. Am Rev Respir Dis 1974;110:88.

20. Mitchell D, Emerson C, Collins J, et al. Transbronchial lung biopsy with the fibreoptic bronchoscope: analysis of results in 433 patients. $\mathrm{Br} \mathrm{J}$ Dis Chest 1981;75:258.

21. Robb J, Melello C, Odom C. Comparison of cytoshuttle and cytocentrifuge as processing methods for nongynecologic cytology specimens. Diagn Cytopathol 1996;14:305.

22. Willcox M, Kervitsky A, Watters L, et al. Quantification of cells recovered by bronchoalveolar lavage. Comparison of cytocentrifuge preparations with the filter method. Am Rev Respir Dis 1988;138:74.

23. Guidelines for the management of adults with hospitalacquired, ventilator-associated, and healthcareassociated pneumonia. Am J Respir Crit Care Med 2005; 171:388.

24. Fagon JY, Chastre J, Wolff M, et al. Invasive and noninvasive strategies for management of suspected ventilator-associated pneumonia. A randomized trial. Ann Intern Med 2000;132:621.

25. Franke KJ, Bruckner C, Szyrach M, et al. The contribution of endobronchial ultrasound-guided forceps biopsy in the diagnostic workup of unexplained mediastinal and hilar lymphadenopathy. Lung 2012;190(2):227-32.

26. Triller N, Dimitrijevic J, Rozman A. A comparative study on endobronchial ultrasound-guided and fluoroscopic-guided transbronchial lung biopsy of peripheral pulmonary lesions. Respir Med 2011; 105(Suppl 1):S74.

27. Andersen $\mathrm{H}$. Transbronchoscopic lung biopsy for diffuse pulmonary diseases. Results in 939 patients. Chest 1978;73:734.

28. Al-Za'abi A, MacDonald S, Geddie W, et al. Cytologic examination of bronchoalveolar lavage fluid from immunosuppressed patients. Diagn Cytopathol 2007;35:710.

29. DeMay RM. A micromiscellany. In: DeMay R, editor. The art and science of cytopathology: exfoliative cytology. Chicago: ASCP Press; 1996. p. 53.

30. Johnson W, Elson C. Respiratory tract. In: Bibbo M, editor. Comprehensive cytopathology. Philadelphia: Saunders; 1991. p. 340.

31. Powers C. Diagnosis of infectious disease: a cytopathologists perspective. Clin Microbiol Rev 1998; 11:341.

32. Minnich S, Taubert K. [The combined application of ultrasound and impulse current]. Zeitschrift fur arztliche Fortbildung 1991;85:668 [in German].

33. Pearlstein DP, Quinn CC, Burtis CC, et al. Electromagnetic navigation bronchoscopy performed by thoracic surgeons: one center's early success. Ann Thorac Surg 2012;93:944.

34. Grinan N, LucernaF, Romero J. Yield of percutaneous aspiration in lung abscess. Chest 1990;97:69.

35. Ruiz- Gonzales A, Falquera M, Nogues A. Is Streptococcus pneumoniae the leading cause of pneumonia of unknown etiology? Am J Med 1999;106:385.

36. Vera-alverez J, Marigil-Gomez M, Garcia-Prats M, et al. Primary pulmonary botryomycosis diagnosed by fine needle aspiration biopsy. Acta Cytol 2006; 50:331.

37. Yang PC, Luh KT, Lee YC, et al. Lung abscesses: US examination and US-guided transthoracic aspiration. Radiology 1991;180:171.

38. Garg S, Handa U, Mohan $\mathrm{H}$, et al. Comparative analysis of various cytohistological techniques in diagnosis of lung diseases. Diagn Cytopathol 2007;35:26.

39. Granville L, Laucirica R, Verstovek G. Clinical significance of cultures collected from fine-needle aspirates. Diagn Cytopathol 2008;36:85.

40. Mayer J. Laboratory diagnosis of nosocomial pneumonia. Semin Respir Infect 2000;15:119.

41. Vuori-Holopainen E, Salo E, Saxen H, et al. Etiological diagnosis of childhood pneumonia by use of transthoracic needle aspiration and modern microbiological methods. Clin Infect Dis 2002;34:583.

42. Bocking $A$, Klose $K, K y l l ~ H$, et al. Cytologic versus histologic evaluation of needle biopsy of the lung, hilum and mediastinum-sensitivity, specificity and typing accuracy. Acta Cytol 1995;39:463.

43. Lohela P, Tikkakoski T, Ammala K, et al. Diagnosis of diffuse lung disease by cutting needle biopsy. Acta Radiol 1994;35:251.

44. Milman N. Percutaneous lung biopsy with semiautomatic, spring-driven fine needle-preliminary results in 13 patients. Respiration 1993;60:289.

45. Sanders C. Transthoracic needle aspiration. Clin Chest Med 1992;13:11.

46. Smyth R, Carty $H$, Thomas $H$, et al. Diagnosis of interstitial lung disease by a percutaneous lung biopsy sample. Arch Dis Child 1994;70:143.

47. Williams A, Santiago S, Lehrman S, et al. Transcutaneous needle aspiration of solitary pulmonary masses: how many passes? Am Rev Respir Dis 1987;136:452.

48. Verma P. Laboratory diagnosis of anaerobic pleuropulmonary infections. Semin Respir Infect 2000;15:114.

49. Berquist TH, Bailey PB, Cortese DA, et al. Transthoracic needle biopsy: accuracy and complications in relation to location and type of lesion. Mayo Clin Proc 1980;55:475.

50. Crosby JH, Hager B, Hoeg K. Transthoracic fineneedle aspiration. Experience in a cancer center. Cancer 1985;56:2504.

51. Larscheid RC, Thorpe PE, Scott WJ. Percutaneous transthoracic needle aspiration biopsy: 
a comprehensive review of its current role in the diagnosis and treatment of lung tumors. Chest 1998; 114:704.

52. Jaklitsch MT, DeCamp MM Jr, Liptay MJ, et al. Video-assisted thoracic surgery in the elderly. A review of 307 cases. Chest 1996;110:751.

53. Travis WD. Lung infections. In: King D, editor. Nonneoplastic disorders of the lower respiratory tract atlas of non tumor pathology. Washington, DC: American Registry of Pathology; 2002. p. 539.

54. File TM. Community-acquired pneumonia. Lancet 2003;362:1991.

55. Mandell LA, Wunderink RG, Anzueto A, et al. Infectious Diseases Society of America/American Thoracic Society consensus guidelines on the management of community-acquired pneumonia in adults. Clin Infect Dis 2007;44(Suppl 2):S27.

56. McCabe C, Kirchner C, Zhang H, et al. Guidelineconcordant therapy and reduced mortality and length of stay in adults with community-acquired pneumonia: playing by the rules. Arch Intern Med 2009;169:1525.

57. American Thoracic Society/Centers for Disease Control and Prevention/Infectious Diseases Society of America: controlling tuberculosis in the United States. Am J Respir Crit Care Med 2005; 172:1169.

58. Athanassa Z, Makris G, Dimopoulos G, et al. Early switch to oral treatment in patients with moderate to severe community-acquired pneumonia: a metaanalysis. Drugs 2008;68:2469.

59. Halm EA, Fine MJ, Marrie TJ, et al. Time to clinical stability in patients hospitalized with communityacquired pneumonia: implications for practice guidelines. JAMA 1998;279:1452.

60. Napolitano LM. Hospital-acquired and ventilatorassociated pneumonia: what's new in diagnosis and treatment? Am J Surg 2003;186:4S.

61. Joseph NM, Sistla S, Dutta TK, et al. Ventilatorassociated pneumonia: a review. Eur J Inter Med 2010;21:360.

62. Niederman MS. De-escalation therapy in ventilatorassociated pneumonia. Curr Opin Crit Care 2006; 12:452.

63. Porzecanski I, Bowton DL. Diagnosis and treatment of ventilator-associated pneumonia. Chest 2006; 130:597.

64. Palmer LB. Aerosolized antibiotics in the intensive care unit. Clin Chest Med 2011;32:559.

65. Palmer LB, Smaldone GC, Chen JJ, et al. Aerosolized antibiotics and ventilator-associated tracheobronchitis in the intensive care unit. Crit Care Med 2008;36(7):2008-13.

66. Niederman M, Chastre J, Corkery K. Inhaled amikacin reduces IV antibiotic use in intubated mechanically ventilated patients [abstract]. Am J Respir Crit Care Med 2007;175:A326.
67. Rattanaumpawan $\mathrm{P}$, Lorsutthitham J, Ungprasert $\mathrm{P}$, et al. Randomized controlled trial of nebulized colistimethate sodium as adjunctive therapy of ventilator-associated pneumonia caused by Gram-negative bacteria. J Antimicrobial Chemother 2010;65:2645.

68. McGrath EE, McCabe J, Anderson PB. Guidelines on the diagnosis and treatment of pulmonary nontuberculous mycobacteria infection. Int J Clin Pract 2008;62:1947.

69. Kunimoto D, Long R. Tuberculosis: still overlooked as a cause of community-acquired pneumoniahow not to miss it. Respir Care Clin N Am 2005;11:25.

70. Storla D, Yimer S, Bjune GA. A systematic review of delay in the diagnosis and treatment of tuberculosis. BMC Public Health 2008;8:15.

71. Gardiner DF, Beavis KG. Laboratory diagnosis of mycobacterial infections. Semin Respir Infect 2000; 15:132.

72. Griffith DE, Aksamit T, Brown-Elliott BA, et al. An official ATS/IDSA statement: diagnosis, treatment, and prevention of nontuberculous mycobacterial diseases. Am J Respir Crit Care Med 2007; 175:367.

73. Dehda K, Booth $\mathrm{H}$, Huggett J, et al. Lung remodeling in pulmonary tuberculosis. J Infect Dis 2005; 192:1201.

74. Lack E, Connor D. Tuberculosis. In: Chandler F, Connor D, Schwartz D, editors. Pathology of infectious disease. Stamford (CT): Appleton \& Lange; 1997. p. 857.

75. Van Dyke P, Hoenacker F, Van Den Brande P, et al. Imaging of pulmonary tuberculosis. Eur Radiol 2003;13:1771.

76. Brantianos P, Swanson J, Torbenson M, et al. Tuberculosis-associated hemophagocytic syndrome. Lancet Infect Dis 2006;6:447-54.

77. Primm T, Lucero C, Falkinham J. Health impacts of environmental mycobacteria. Clin Micro Rev 2004; 17:98.

78. Tortoli E. Impact of genotypic studies on mycobacterial taxonomy: the new mycobacteria of the 1990s. Clin Microbiol Rev 2003;16:319.

79. Field S, Cowie R. Lung disease due to more common mycobacteria. Chest 2006;129:1653.

80. Glassroth J. Pulmonary disease due to nontuberculous mycobacteria. Chest 2008;133:243.

81. Johnson M, Waller E, Leventhal JP. Non tuberculous mycobacterial pulmonary disease. Curr Opin Pulm Med 2008;14:203.

82. Horsburgh CR Jr, Feldman S, Ridzon R. Practice guidelines for the treatment of tuberculosis. Clin Infect Dis 2000;31:633.

83. Caminero JA, Sotgiu G, Zumla A, et al. Best drug treatment for multidrug-resistant and extensively drug-resistant tuberculosis. Lancet Infect Dis 2010;10:621. 
84. Dave BR, Sharma A, Kalva SP, et al. Nine-year single-center experience with transcatheter arterial embolization for hemoptysis: medium-term outcomes. Vasc Endovascular Surg 2011;45:258.

85. Kapur S, Louie BE. Hemoptysis and thoracic fungal infections. Surg Clin North Am 2010;90:985.

86. Andrejak C, Parrot A, Bazelly B, et al. Surgical lung resection for severe hemoptysis. Ann Thorac Surg 2009;88:1556.

87. Jougon J, Ballester M, Delcambre F, et al. Massive hemoptysis: what place for medical and surgical treatment. Eur J Cardiothorac Surg 2002;22:345.

88. Shigemura N, Wan IY, Yu SC, et al. Multidisciplinary management of life-threatening massive hemoptysis: a 10-year experience. Ann Thorac Surg 2009;87:849.

89. Karmy-Jones R, Cuschieri J, Vallieres E. Role of bronchoscopy in massive hemoptysis. Chest Surg Clin N Am 2001;11:873.

90. Kato A, Kudo S, Matsumoto K, et al. Bronchial artery embolization for hemoptysis due to benign diseases: immediate and long-term results. Cardiovasc Intervent Radiol 2000;23:351.

91. Rabkin JE, Astafjev VI, Gothman LN, et al. Transcatheter embolization in the management of pulmonary hemorrhage. Radiology 1987;163:361.

92. Remy-Jardin M, Wattinne L, Remy J. Transcatheter occlusion of pulmonary arterial circulation and collateral supply: failures, incidents, and complications. Radiology 1991;180:699.

93. Uflacker R, Kaemmerer A, Neves C, et al. Management of massive hemoptysis by bronchial artery embolization. Radiology 1983;146:627.

94. Yoon W, Kim JK, Kim YH, et al. Bronchial and nonbronchial systemic artery embolization for lifethreatening hemoptysis: a comprehensive review. Radiographics 2002;22:1395.

95. Saubolle MA. Fungal pneumonias. Semin Respir Infect 2000;15:162.

96. Haque A, McGinnis MR. Fungal infections. In: Tomashefski J, Cagle P, Farver C, et al, editors. Dail and Hammar's pulmonary pathology. New York: Springer; 2008. p. 349.

97. Sabonya R. Fungal disease, including pneumocystis. In: Churg A, Meyers J, Tazelaar H, et al, editors. Thurlbeck's pathology of the lung. New York: Thieme; 2005. p. 283.

98. Irwin R, Rinaldi M, Walsh T. Zygomycosis of the respiratory tract. In: Sarosi G, Davies S, editors. Fungal diseases of the lung. 3rd edition. Philadelphia: Lippincott Williams \& Wilkins; 2000. p. 163.

99. Karnak D, Avery R, Gilder T, et al. Endobronchial fungal disease: an under recognized entity. Respiration 2007;74:88.

100. Herbrecht R, Denning DW, Patterson TF, et al. Voriconazole versus amphotericin B for primary therapy of invasive aspergillosis. N Engl J Med 2002;347:408.

101. Walsh TJ, Anaissie EJ, Denning DW, et al. Treatment of aspergillosis: clinical practice guidelines of the Infectious Diseases Society of America. Clin Infect Dis 2008;46:327.

102. Marr KA, Boeckh M, Carter RA, et al. Combination antifungal therapy for invasive aspergillosis. Clin Infect Dis 2004;39:797.

103. Singh N, Limaye AP, Forrest G, et al. Combination of voriconazole and caspofungin as primary therapy for invasive aspergillosis in solid organ transplant recipients: a prospective, multicenter, observational study. Transplantation 2006;81:320.

104. Sole A. Invasive fungal infections in lung transplantation: role of aerosolised amphotericin B. Int J Antimicrobial Agents 2008;32(Suppl 2):S161.

105. Rogers TR. Treatment of zygomycosis: current and new options. J Antimicrobial Chemother 2008; 61(Suppl 1):i35.

106. Treanor J. Respiratory infections. In: Richman D, Whitley R, editors. Clinical virology. New York: Churchhill-Livingston; 1997. p. 5.

107. Storch GA. Diagnostic virology. Clin Infect Dis 2000;31:739.

108. Gilliam-Ross L. Emerging respiratory viruses: challenges and vaccine strategies. Clin Microbiol Rev 2006; 19:614.

109. Kahn J. Newly identified respiratory viruses. Pediatr Infect Dis J 2007;26:745.

110. Hidron Al, Low CE, Honig EG, et al. Emergence of community-acquired methicillin-resistant Staphylococcus aureus strain USA300 as a cause of necrotising community-onset pneumonia. Lancet Infect Dis 2009;9:384.

111. Hageman JC, Uyeki TM, Francis JS, et al. Severe community-acquired pneumonia due to Staphylococcus aureus, 2003-04 influenza season. Emerg Infect Dis 2006;12:894.

112. Rabella N, Rodriguez P, Labeaga R, et al. Conventional respiratory viruses recovered from immunocompromised patients: clinical considerations. Clin Infect Dis 1999;28:1043.

113. Ruuskanen O, Putto A, Sarkkinen H, et al. C-reactive protein in respiratory virus infections. J Pediatr 1985; 107:97.

114. Anjuna V, Colby T. Pathologic features of lung biopsy specimens from influenza pneumonia cases. Hum Pathol 1994;25:47.

115. Taubenberger J, Morens D. The pathology of influenza virus infections. Ann Rev Pathol 2008;3:499.

116. Harper SA, Bradley JS, Englund JA, et al. Seasonal influenza in adults and children-diagnosis, treatment, chemoprophylaxis, and institutional outbreak management: clinical practice guidelines of the Infectious Diseases Society of America. Clin Infect Dis 2009;48:1003. 
117. Michalopoulos A, Kasiakou SK, Mastora Z, et al. Aerosolized colistin for the treatment of nosocomial pneumonia due to multidrug-resistant Gramnegative bacteria in patients without cystic fibrosis. Crit Care 2005;9(1):R53-9.

118. Kwa AL, Loh C, Low JG, et al. Nebulized colistin in the treatment of pneumonia due to multidrug-resistant Acinetobacter baumannii and Pseudomonas aeruginosa. Clin Infect Dis 2005;41(5):754-7.

119. Berlana D, Llop JM, Fort E, et al. Use of colistin in the treatment of multiple-drug-resistant gram-negative infections. Am J Health Syst Pharm 2005;62(1):39-47.

120. Michalopoulos A, Fotakis D, Virtzili S, et al. Aerosolized colistin as adjunctive treatment of ventilator- associated pneumonia due to multidrug-resistant Gram-negative bacteria: a prospective study. Respir Med 2008;102(3):407-12.

121. Kofteridis DP, Alexopoulou C, Valachis A, et al. Aerosolized plus intravenous colistin versus intravenous colistin alone for the treatment of ventilator-associated pneumonia: a matched case-control study. Clin Infect Dis 2010;51(11):1238-44.

122. Korbila IP, Michalopoulos A, Rafailidis PI, et al. Inhaled colistin as adjunctive therapy to intravenous colistin for the treatment of microbiologically documented ventilator-associated pneumonia: a comparative cohort study. Clin Microbiol Infect 2010;16(8):1230-6. 